\title{
Accelerated eutrophication and toxicity in tropical reservoir water and sediments: an ecotoxicological approach
}

\author{
A. C. Rietzler $^{1}$ - C. R. Botta ${ }^{2}$ - M. M. Ribeiro ${ }^{1}$ - O. Rocha ${ }^{3}$ - A. L. Fonseca ${ }^{4}$
}

Received: 6 April 2016 / Accepted: 14 September 2016 / Published online: 19 October 2016

(C) Springer-Verlag Berlin Heidelberg 2016

\begin{abstract}
The aim of this study was to jointly show the results of three independent ecotoxicological studies performed to investigate pollutants in three Brazilian tropical reservoirs undergoing accelerated eutrophication. In order to accomplish this goal, the full toxicity identification and evaluation procedure (TIE approach) was performed, at Pampulha (Minas Gerais State) and Salto Grande and Barra Bonita reservoirs (São Paulo State). Acute and chronic toxicity tests were performed using the cladocerans Daphnia similis and Ceriodaphnia dubia (exotic) and Daphnia laevis and Ceriodaphnia silvestrii (native) as test organisms. Results from TIE procedure stage I indicated the existence of nonpolar organic and filterable compounds in the water from Pampulha, probably cyanotoxins, and oxidants as part of the toxic agents. TIE results for sediments identified ammonia (Pampulha and Salto Grande), organic compounds (Pampulha), metals (Pampulha, Barra Bonita, and Salto Grande), and acidity (Salto Grande) as responsible for toxicity. Whole-sediment remediation experiments for Pampulha reservoir confirmed, through reproduction decrease, ammonia and organic compounds as contaminants. Such pollutants represent threats to
\end{abstract}

Responsible editor: Philippe Garrigues

A. C. Rietzler

acrietzler@gmail.com

1 General Biology Department, Biological Sciences Institute, Federal University of Minas Gerais, Belo Horizonte, Brazil

2 Centre of Water Resources and Environmental Studies, State University of São Paulo, São Carlos, Brazil

3 Department of Ecology and Evolutionary Biology, Federal University of São Carlos, São Carlos, Brazil

4 Natural Resources Institute, Federal University of Itajubá, Itajubá, Brazil aquatic biota and must be prevented. Higher temperatures as predicted from global climate change will severely affect tropical shallow reservoirs, accelerating eutrophication, the release of contaminants from sediments, and increasing toxicity.

Keywords Ecotoxicology · Freshwater contaminants · Cladocerans $\cdot$ Cyanobacteria $\cdot$ Ammonia $\cdot$ Metals . Remediation

\section{Introduction}

Thousands of potentially toxic compounds are found in the world's waters as shown by chemical analysis. A prime concern with environmental safety is the toxic effect of pollutants (Ankley and Schubauer-Beringan 1995; Manahan 2013). Water quality issues are nowadays in the list of priorities of almost every country in Earth, from the most developed nations of the Northern Hemisphere to countries in the first steps of industrial development in the South (Onda et al. 2012; Cross and Latorre 2015).

As human population and technology exponentially increase, meeting energy and material demands as well as handling waste products safely and sustainably have become the greatest challenge for mankind. Most substances contributing to environmental toxicity are processed and released by man. These include organic and inorganic chemicals, radionuclides, herbicides, trace elements, and many other types of pollutants (Manahan 2013).

Eutrophication, the nutrient enrichment of water bodies, is perhaps the most widespread process affecting water quality and limiting its use for drinking, irrigation, and leisure. It has been shown to be the main driver of cyanobacteria abundance and persistence (Codd 2000; Downing et al. 2001; Davis and 
Koop 2006), especially in the tropics and subtropics (Reynolds et al. 2000; Chorus 2001).

Tropical reservoirs are usually shallow and frequently exposed to high temperatures and nutrient loadings, favoring cyanobacterial blooms and sediment anoxia (Codd 2000; Huszar et al. 2000). Potentially toxic cyanobacteria have been more and more detected in tropical freshwater environments (Takenaka et al. 2007; Valério et al. 2008; Ferrão-Filho et al. 2009), related to changes in trophic state of the lakes and also to global climate change (Larouque-Tobler et al. 2010; Newcombe et al. 2012). As an example, a recent investigation on the phytoplankton community of a Brazilian urban eutrophic system (Pampulha reservoir) has shown toxic strains of Cylindrospermopsis raciborskii (Jardim et al. 2010) to increase in density over the past few years. These findings indicate a risk for aquatic biota and water quality, considering that cyanotoxins play a powerful role under tropical climates (Sotero-Santos et al. 2006; Monteiro et al. 2006; Molica and Azevedo 2009; Vasconcelos et al. 2011) and present trends of global climate change (Dodson 2010). Ecotoxicological studies are necessary in this context, especially if using native organisms for evaluating water quality (Böhrer-Morel et al. 2005; Takenaka et al. 2007; Kuhl et al. 2010) and sediment remediation (Janke et al. 2011; Yamada et al. 2012; Jeppesen et al. 2014).

Beside the occurrence of cyanobacteria, eutrophic urban reservoirs present a number of other toxic compounds. Identification of such contaminants is a prerequisite for control and recovery and is important to determine the presence and magnitude of toxicants (Maltby et al. 1995). The toxicity identification and evaluation (TIE) procedures developed in the 1980s combine toxicity tests and physical and chemical analysis (USEPA 1991, 1992) or, in other words, chemistry and ecotoxicology in order to identify the type of substances responsible for the measured toxicity. They successfully identify compounds causing acute effects in more than $90 \%$ of toxic samples analyzed (USEPA 1992; Thomas et al. 2003) and have been applied to water and sediments in marine and freshwaters (Burgess et al. 1995, 1997; Anderson et al. 2010; Greenstein et al. 2014) or effluents (Chan et al. 2003; Yu et al. 2003). Their utilization for water and sediment samples has identified cationic metals, nonpolar organics, and ammonia, among other contaminants (Schubauer-Beringan and Ankley 1991; Ankley and Schubauer-Beringan 1995; Van Sprang and Janssen 1997; Ho et al. 2002; Araujo et al. 2006; Buratini et al. 2007; Nilin et al. 2007; Picone et al. 2008). In a recent study carried out at Funil reservoir, Rio de Janeiro State, Brazil, Matos et al. (2014), have also identified cyanotoxins among the compounds involved in water toxicity.

The TIE procedures combine toxicity evaluation with identification and quantification of toxic compounds in three phases: phase I characterizes physical and chemical properties of toxic substances through manipulation, changing bioavailability of compounds with similar properties. Phases II and III provide quantification and confirmation of toxicants identified in phase I (USEPA 1992).

In reservoir sediments, whose evaluation is still not required by Brazilian environmental agencies, some ecotoxicological studies have shown ammonia as a major contaminant (Araujo et al. 2006; Nilin et al. 2007; Matos et al. 2014). However, most of such studies in Brazilian reservoirs have so far evidenced water and/or sediment toxicity, with no indication of pollutants responsible for it. Our main goal was to investigate the most probable toxic agents in the selected tropical reservoirs presenting data we produced at relatively recent but not on superimposed periods of time. There were specific objectives for filling specific knowledge gaps as for Salto Grande and Barra Bonita reservoirs or getting updated ecotoxicological information as in the case of Pampulha reservoir. They included a detailed study on water toxicity, emphasizing toxic cyanobacteria, evaluation and identification of water and sediment toxicants in such environments, and knowledge that might be useful for management planning and remediation actions.

\section{Materials and methods}

\section{Studied reservoirs}

\section{Pampulha reservoir, Minas Gerais state}

Pampulha reservoir is an urban eutrophic medium-sized reservoir located in the metropolitan area of Belo Horizonte, Minas Gerais state, at $19^{\circ} 51^{\prime} \mathrm{S}-43^{\circ} 58^{\prime} \mathrm{W}$, with an area of $1.82 \mathrm{~km}^{2}$, mean depth of $5.0 \mathrm{~m}$, and retention time of 76.7 days (Fig. 1). The reservoir receives high inputs of domestic and industrial effluents from its tributaries. Nowadays, eutrophication and industrial waste contamination are still basic problems.

\section{Barra Bonita and Salto Grande reservoirs, São Paulo state}

Barra Bonita and Salto Grande reservoirs are located in the Tietê River basin (Fig. 1) at the most populated and industrialized area of São Paulo state. Barra Bonita, the largest, located at $22^{\circ} 29^{\prime} \mathrm{S}-48^{\circ} 34^{\prime} \mathrm{W}$, has a flooded area of $324.84 \mathrm{~km}^{2}$, perimeter of $525 \mathrm{~km}$, average and maximum depths of 10 and $30 \mathrm{~m}$, respectively, total maximum volume of $10.6 \times 10^{8} \mathrm{~m}^{3}$, and average retention time of 30 days. Its drainage basin has an extension of $32,330 \mathrm{~km}^{2}$ and its main tributaries, the rivers Tiete and Piracicaba, receive great discharges of wastewater from both urban centers and agricultural areas.

Salto Grande reservoir is formed by the Atibaia River, an affluent of Piracicaba River, in the city of Americana, located at $22^{\circ} 44^{\prime} \mathrm{S}-44^{\circ} 19^{\prime} \mathrm{W}, 530 \mathrm{~m}$ altitude with mean and 
Fig. 1 Map showing location of Pampulha, Barra Bonita, and Salto Grande reservoirs in Southeast Brazil and the sampling sites on each reservoir

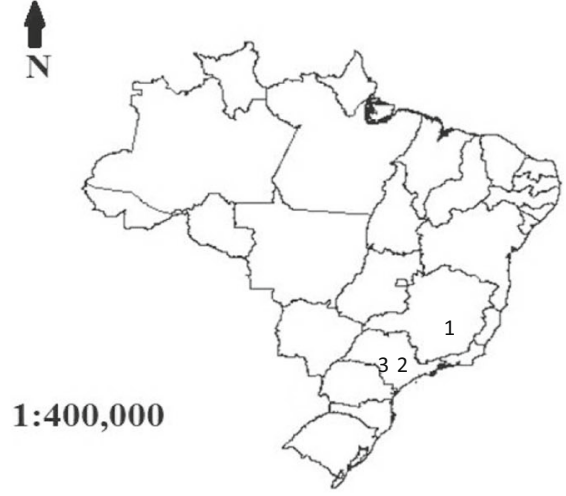

1-Pampulha reservoir, $\mathrm{MG}$

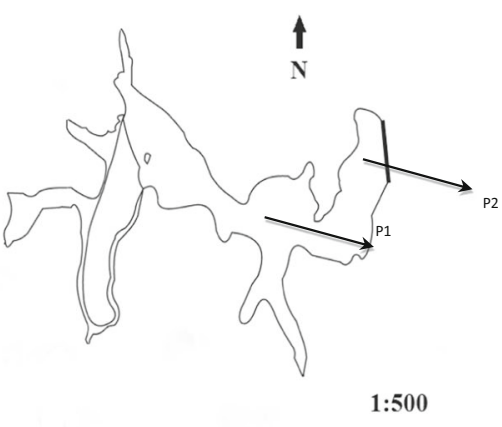

2-Barra Bonita reservoir, SP

3- Salto Grande reservoir, SP

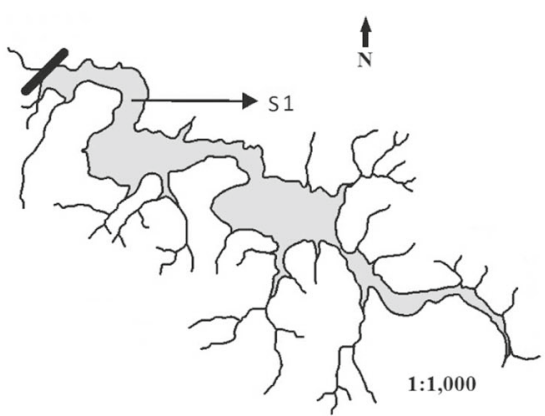

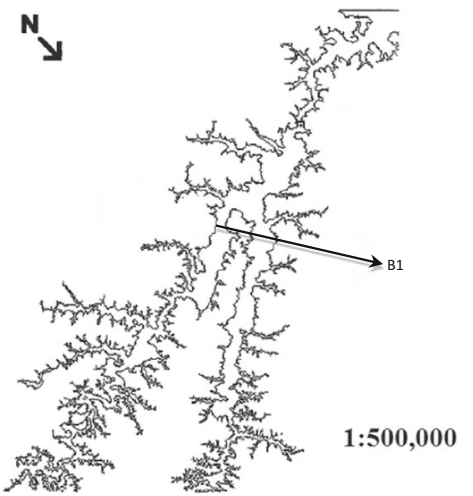

maximum depths of 9.0 and $19.0 \mathrm{~m}$, respectively. Mean retention time is 30 days, and its drainage basin encompasses $2650 \mathrm{~km}^{2}$. Its main water source, the Atibaia River, receives contributions from several small tributaries draining urban centers.

\section{Water and sediment samplings for ecotoxicological evaluation}

Five-liter samples of sub-superficial water were monthly collected in one sampling site of Pampulha reservoir with plastic bottles and used for all acute and chronic toxicity tests (P1, Figs. 1 and 2) between March 2010 and April 2011. For the TIE procedure, both water and sediments were collected from two sites (P1 and P2, Figs. 1 and 2) in April and December 2011, June 2012, and June 2014. Water samplings were collected just as previously described and for sediment three to ten samples were collected with plastic recipients, joined to obtain $5 \mathrm{~kg}$ of sediment in each site, and homogeneized. Samples were maintained in polystyrene boxes on ice for transportation to the laboratory and then refrigerated at $4{ }^{\circ} \mathrm{C}$ for 7 to 8 days, during which experiments were performed (ABNT 2010).

The study in Pampulha reservoir was independent from the one in Barra Bonita and Salto Grande reservoirs. Sampling methods and experimental design were slightly different (TIE with both water and sediment in Pampulha and only with sediment in the other reservoirs) and test organisms also varied. In both Barra Bonita and Salto Grande, sediment samples were collected with an Eckman-Birge dredge (sampling area of $202.2 \mathrm{~cm}^{2}$ ), homogenized in 10 -L plastic bucket, stored in plastic recipients at $4{ }^{\circ} \mathrm{C}$, and used for elutriate preparation for a maximum of 30 days. Sediment samples for TIE were collected in June 2000 and October 2001, at one site in the reservoir, near the entrance of Tietê River, considered the main source of pollutant input from São Paulo city and surroundings. In Salto Grande, samplings were carried out at one site near dam.

\section{Zooplankton culturing for ecotoxicological tests}

For toxicity tests of the water of Pampulha reservoir, the test organisms used in the present study were cultured in natural, non-reconstituted water, neutral $\mathrm{pH}$, conductivity of 130.0 to $150.0 \mu \mathrm{S} \mathrm{cm}{ }^{-1}$, and hardness around 40.0 to $44.0 \mathrm{mg} \mathrm{L}^{-1}$ $\mathrm{CaCO}_{3}$. Test organism stock cultures were kept under controlled temperature of $23 \pm 1{ }^{\circ} \mathrm{C}$ (Daphnia similis) or $25 \pm 1{ }^{\circ} \mathrm{C}$ (Daphnia laevis and Ceriodaphnia silvestrii) with a photoperiod of $12 \mathrm{~h}$.

In the case of Barra Bonita and Salto Grande reservoirs, the test organism, Ceriodaphnia dubia, was cultured under $25 \pm 2{ }^{\circ} \mathrm{C}$, reconstituted water, $\mathrm{pH} 7.0-7.6$, conductivity of 


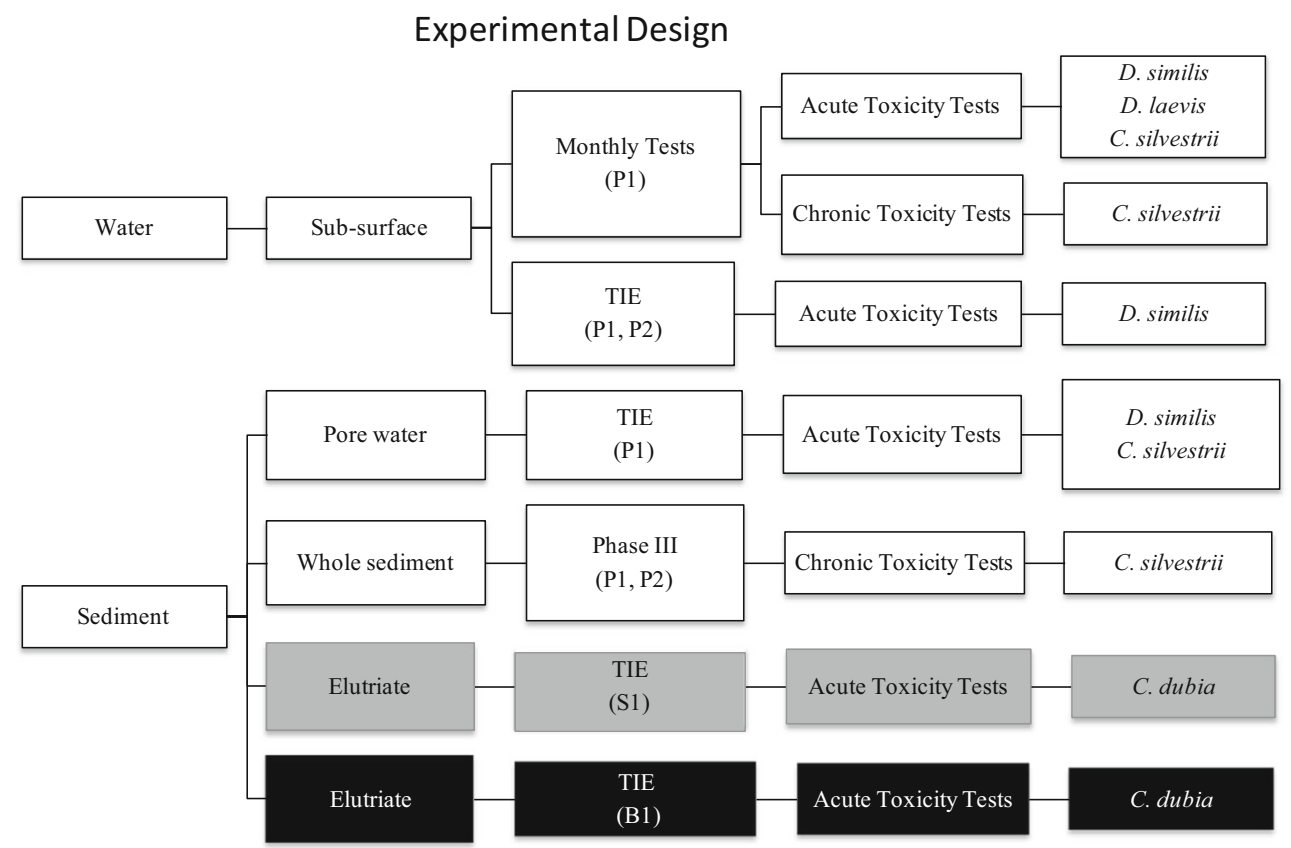

Fig. 2 Diagram representing water and sediment experimental design, including TIE steps (phases I-III) for Pampulha (white boxes), Barra Bonita (black boxes), and Salto Grande (gray boxes) reservoirs

$160.0 \mu \mathrm{S} \mathrm{cm}^{-11}$, hardness of $40-48 \mathrm{mg} \mathrm{L}^{-1} \mathrm{CaCO}_{3}$, and photoperiod of $16 \mathrm{~h}$.

The organisms were daily fed with the alga Raphidocelis subcapitata $\left(10^{6}\right.$ cells per $\left.\mathrm{mL}\right)$ and a mixture of fermented fish ration + yeast, every 2 days. Sensitivity tests $\left(48-\mathrm{h} \mathrm{EC}_{50}\right)$ were conducted monthly with sodium chloride as reference toxicant following ABNT standard protocol (ABNT 2010).

\section{Pore water extraction and elutriate procedures}

For sediment toxicity tests, pore water extraction was obtained by centrifugation of sediments from all reservoirs for $30 \mathrm{~min}$ at $3000 \mathrm{rpm}$ (Giesy et al. 1988). Elutriate was prepared by mechanical shaking of a suspension of water and sediment in a ratio of $4: 1(v / w)$ for a period of 6 to $8 \mathrm{~h}$ (Pampulha) and 12 to $16 \mathrm{~h}$ (Barra Bonita and Salto Grande). After settling, the overlying water was transferred to dark glass bottles and stored at $8{ }^{\circ} \mathrm{C}$ until use in toxicity tests and TIE (SETAC 1993).

\section{Water and sediment toxicity tests}

All toxicity tests using water and sediment samples were performed with daphnid cladocerans. In the case of sediments, cladocerans, instead of benthic organisms, were considered due to their higher (Giesy et al. 1990) or equal sensitivity (Burton et al. 2005; Hoffman et al. 2002), epibenthic behavior, and assuming, according to Hoffman et al. (2002) and USEPA (2007), that they are appropriate test organisms for sediment tests including pore water, elutriate, as well as whole sediment. The sediment studies conducted in 2000 and 2001 for Barra Bonita and Salto Grande reservoirs adopted C. dubia, using the standardized protocol available (ABNT 1995). Besides D. similis, C. silvestrii, a native species, was adopted as test organism for Pampulha sediment studies, according to a Brazilian protocol more recently standardized (ABNT 2005).

For acute toxicity tests, daphnids $24 \mathrm{~h}$ old were placed in three or four replicates of $10 \mathrm{~mL}$ aqueous samples (water, pore water. or elutriate) and five organisms per vial, in $30-\mathrm{mL}$ beakers. In the case of the monthly water toxicity tests conducted for Pampulha reservoir, $20 \mathrm{~mL}$ of raw water and 10 organisms (D. similis, D. laevis, and C. silvestrii) per vial were exposed. The test concentrations for all TIE phase I procedures were 100, 50, 25, and $12.5 \%$. The vials were incubated for $48 \mathrm{~h}$ at $24 \pm 1{ }^{\circ} \mathrm{C}$, and after which, immobility and/or mortality was recorded. The results were expressed as $48-\mathrm{h} \mathrm{EC}_{50}$ statistically estimated by the trimmed Spearman-Karber method computer version 1.5 (Hamilton et al. 1977) or as immobility/ mortality percentage at a given concentration (USEPA 1991; ABNT 2010).

Chronic toxicity tests were carried out with raw water and whole sediments, using $<24$-h-old $C$. silvestrii and 10 replicates of water (monthly tests) and sediment/water (1:4 weight/volume; TIE phase III) containing one neonate per replicate, respectively. The tests were incubated for 7-8 days, at $25 \pm 1{ }^{\circ} \mathrm{C}$ with photoperiod of $12 \mathrm{~h}$. Every 2 days, $1 / 3$ of test solution was renewed and the 
Water TIE

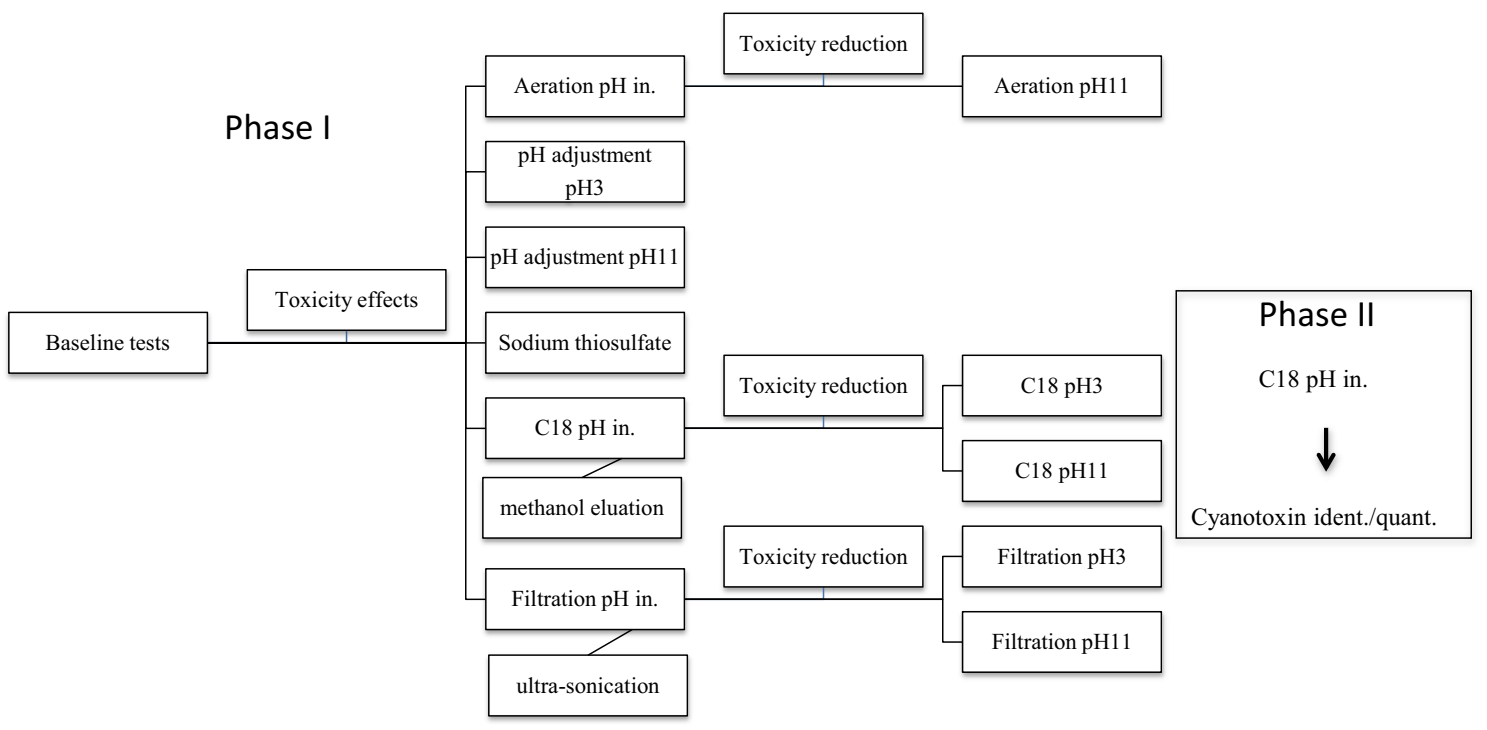

Sediment TIE

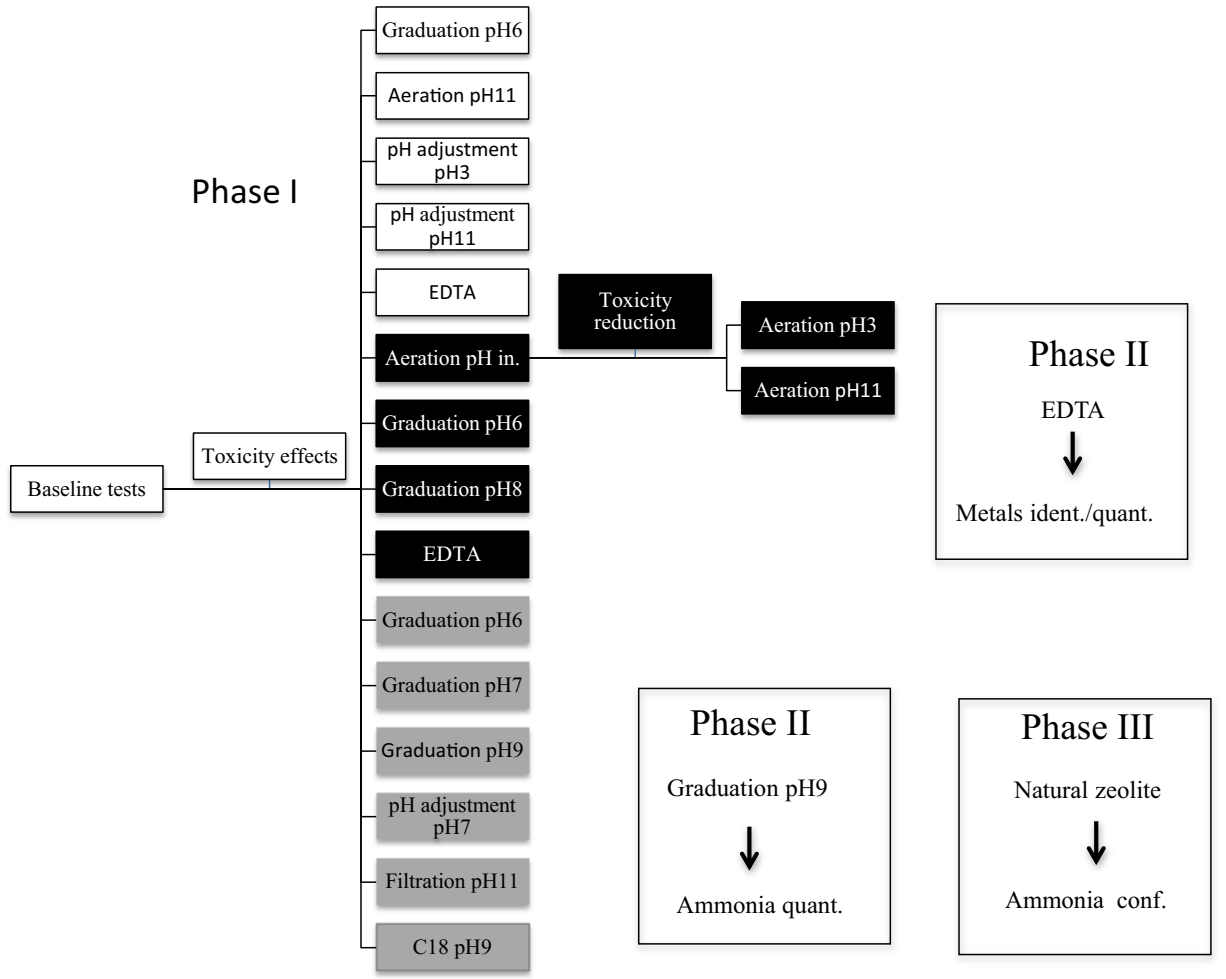

Fig. 2 (continued)

number of surviving animals and neonates recorded (Burton and MacPherson 1995; ABNT 2010). Differences between control group and samples were determined by the Bonferroni test-TOXSTAT 3.0 computer program (Gulley 1996).

\section{Post-exposure experiments}

Immobile organisms from the monthly acute toxicity tests were removed, fed, and kept in culturing water for $24 \mathrm{~h}$ to verify recovery capacity. Results were expressed as percentage of 
mobile organisms. These procedures were based on FerrãoFilho et al. (2010).

\section{Toxicity identification and evaluation — phase I}

Water samples from Pampulha and sediment samples from Pampulha, Salto Grande, and Barra Bonita were used for TIE procedures. Water aliquots were subjected to the standardized physical or chemical treatments to remove, modify, or make unavailable substances or groups of substances (USEPA 1991, 2007). Each subsample had its toxic effect tested. We determined whether there was absence, reduction, or maintenance of effects compared to baseline tests (without manipulation) of acute toxicity carried out for D. similis (Pampulha sub-superficial water), C. dubia (elutriate from Barra Bonita and Salto Grande), D. similis, and C. silvestrii (pore water from Pampulha).

For sub-superficial water and pore water from Pampulha, the TIE procedures were $\mathrm{pH}$ adjustment tests ( $\mathrm{pH} 3$ and 11), graduated $\mathrm{pH}$ tests ( $\mathrm{pH} 6$ and 9), solid-phase extraction with C18 columns ( $\mathrm{pH} 3$, initial $\mathrm{pH}$, and $\mathrm{pH}$ 9), filtration tests in cellulose acetate filters with $0.45 \mu \mathrm{m}(\mathrm{pH} 3$, initial $\mathrm{pH}$, and $\mathrm{pH}$ 11), aeration tests ( $\mathrm{pH} 3$, initial $\mathrm{pH}$, and $\mathrm{pH} 11)$, and sodium thiosulfate and ethylenediamine tetraacetic acid (EDTA) addition tests (Fig. 2).

The procedures used for the sediment elutriate from Barra Bonita reservoir were graduated $\mathrm{pH}$ tests $(\mathrm{pH} 7$, $\mathrm{pH} 6$, and $\mathrm{pH} 8)$, aeration tests $(\mathrm{pH} \mathrm{3}$, initial $\mathrm{pH}$, and $\mathrm{pH} 11$ ) and EDTA addition tests. The procedures used for the sediment elutriate from Salto Grande reservoir were graduated $\mathrm{pH}$ tests $(\mathrm{pH} 6, \mathrm{pH} \mathrm{7}$, and $\mathrm{pH} 9)$, adjustment $\mathrm{pH}$ tests $(\mathrm{pH} 7, \mathrm{pH} \mathrm{11)}$, and solid-phase extraction with $\mathrm{C} 18$ columns (pH initial, $\mathrm{pH}$ 9) (Fig. 2).

Test results without toxicity were expressed as non-toxic (NT). Data analysis for all phases included $48-\mathrm{h} \mathrm{EC}_{50}$ and confidence intervals $(95 \% \mathrm{CI})$ estimated statistically by the trimmed Spearman-Karber method computer version 1.5 (Hamilton et al. 1977) or as immobility/mortality percentage at a given concentration (USEPA 1991; ABNT 2011). After the analysis, toxic units (TU) were calculated as $100 / \mathrm{EC}_{50}$.

\section{Toxicity recovery tests}

After extraction of adsorbed pollutants in $\mathrm{C} 18$ column, columns were eluted with $2 \mathrm{~mL}$ of methanol and these extracts were tested to evaluate toxicity recovery of $D$. similis during 24-h exposure time. Otherwise, after filtration, filters were ultra-sonicated for $1 \mathrm{~h}$ with the dilution water in an ultrasound bath apparatus or with culturing/dilution water in neutral $\mathrm{pH}$ or $\mathrm{pH} 3$ (for metals) and the sonicated extract was tested to evaluate toxicity recovery.
Toxicity identification and evaluation-phases II/III

Phase II (identification) for water from Pampulha included the quantification of cyanotoxins. For Barra Bonita and Salto Grande, phase II included quantification of ammonia and metals. Phase III (toxicity confirmation procedures) included acid-volatile sulfides (AVS), simultaneously extracted metals (SEM), and removal of ammonia via natural zeolite (Fig. 2).

\section{Cyanotoxin quantification}

During the second and third TIE procedures, water samples from Pampulha reservoir, collected in December 2011 and June 2012, were filtered in C18 column and eluted in acetic acid $500 \mu \mathrm{M}$. The quantification was made by highperformance liquid chromatography (HPLC) by the postcolumn derivatization method (Oshima 1995) in a Shimadzu/CLASS VP apparatus with fluorescence detector (RF-10A XL) adjusted to $330 \mathrm{~nm}$ of excitation and $390 \mathrm{~nm}$ of emission, using a $20-\mu \mathrm{L}$ loop, reverse column Merck LC18 (Lichrocart ${ }^{\circledR} 150 \mathrm{~mm} \times 4.6 \mathrm{~mm} \varnothing, 5 \mu \mathrm{m}$ ).

Microcystins were also quantified by HPLC-MS/MS, after water sample filtration in $\mathrm{C} 18$ column and elution in methanol $100 \%$, according to Spoof et al. (2003). Conditions were as follows: column Kinetex $2.6 \mu \mathrm{C} 18$ $100 \mathrm{~A}(50 \times 2.10 \mathrm{~mm})$; mobile phase A, $5 \mathrm{mM}$ ammonium acetate in water and $0.1 \%$ formic acid; mobile phase $\mathrm{B}$, $5 \mathrm{mM}$ ammonium acetate in acetonitrile and $0.1 \%$ formic acid; flow rate, $450 \mathrm{~mL} \mathrm{~min}^{1}$; injection volume, $10 \mathrm{~mL}$; and gradient, 0 to $2 \min 85 \% \mathrm{~A}$ and $15 \% \mathrm{~B}, 6 \min 65 \% \mathrm{~A}$ and $35 \% \mathrm{~B}, 10 \min 15 \% \mathrm{~A}$ and $85 \% \mathrm{~B}$, and $15 \min 85 \% \mathrm{~A}$ and $15 \% \mathrm{~B}$. The mass spectrometer was fitted with an electrospray ionization source ( $\mathrm{Li}$ et al. 2009) operated in positive ion mode.

\section{Metal and ammonia quantification}

The metal concentrations were determined by the method of Salomons and Forstner (1984). The simultaneous extraction of AVS and metals was based on procedures by Allen et al. (1993). The AVS was quantified spectrophotometrically by methylene blue method (APHA 1992) using a HACH Spectrophotometer, DR/2010.

The ammonia concentrations were measured spectrophotometrically, using a Hach DR/2010 spectrophotometer (Hach, Loveland, CO, USA). Ammonia compounds combine with chlorine to form monochloramine that reacts with salicylate, forming 5-aminosalicylate, which is oxidized in the presence of a catalyst (sodium nitroprusside) to form a colored compound (Besser et al. 1998). 


\section{Experiments on remediation}

Total sediment samples (100 g each) were used in three treatments on remediation experiments using activated carbon and synthetic zeolite with specificity for ammonia as chelating compounds: in treatment I, $20.0 \mathrm{~g}$ of each compound was added; in treatments II and III, 10.0 and $7.5 \mathrm{~g}$ were, respectively, added. Procedures were based on TIE protocol for total sediment (USEPA 2007). Statistical analysis was performed by Tukey's method of multiple comparisons-TOXSTAT 3.0 computer program (Gulley 1996).

\section{Results}

\section{Monthly water toxicity tests}

Water tests carried out with samples from Pampulha reservoir from March 2010 to April 2011 showed acute toxicity effects (immobility) on D. similis and D. laevis in all months, except in August and September 2010 for both species and January 2011 for D. laevis (Figs. 3 and 4). After each assay, the specimens of $D$. similis and $D$. laevis were transferred to culture water and did recover from immobility in most post-exposure experiments (Figs. 3 and 4), except in November 2010.

In the case of $C$. silvestrii, sub-surface raw water acute toxicity effects were detected only in November 2010 (data not shown). Moreover, although with no acute toxicity effects found for both Daphnia species, chronic toxicity assays conducted with sub-surface raw water samples from September 2010 and January 2011 resulted in significant decrease on C. silvestrii reproduction (Fig. 5).

\section{Water TIE experiments}

Water TIE results from Pampulha conducted in April 2011 (sampling sites P1 and P2), December 2011 and June 2012 (P1) and May-June 2014 (P2), are presented in Tables 1 and 2. No toxic effects were detected in May-June 2014 (P1) and December 2011 and June 2012 (P2).

The main TIE results for site P1 in April and December of 2011 and June 2012 were toxicity reduction after aeration and sodium thiosulfate treatment, filtration, and extraction in C18 column and $\mathrm{pH}$ adjustments. These results indicated volatile and oxidable compounds (April 2011), acid and basic organic compounds (April 2011 and June 2012), nonpolar organic compounds' pH dependency (December 2011), and filterable compounds in all three periods (Table 1).

For site $\mathrm{P} 2$, the results indicated nonpolar organic and volatile compounds in April 2011 (toxicity reduction with filtration and $\mathrm{C} 18$ extraction at initial $\mathrm{pH}$ and $\mathrm{pH} 3$ steps) and organic acids and bases, nonpolar organics, and filterable compounds in May-June 2014 (total toxicity reduction for
pH 3 and pH 11 adjustments, filtration, and C18 column extraction at initial $\mathrm{pH}$ ) (Table 2).

\section{Cyanotoxin quantification}

Cyanotoxin analyses through $\mathrm{C} 18$ column elution suggested traces of saxitoxins and detected microcystins $\left(183.0 \mu \mathrm{g} \mathrm{L}^{-1}\right)$ in December 2011 and saxitoxins $\left(2.49 \mu \mathrm{g} \mathrm{Eq} \mathrm{STX} \mathrm{L}{ }^{-1}\right)$ in June 2012.

\section{Sediment TIE experiments}

\section{Pampulha reservoir}

The 48-h $\mathrm{EC}_{50}$ for the baseline toxicity tests with pore water performed with $D$. similis and C. silvestrii in June 2012 confirmed the toxic effects for both organisms, although higher effects on $C$. silvestrii. The TIE phase I results showed that toxicity was totally removed at $\mathrm{pH} 6$ in $\mathrm{pH}$ graduated test and at $\mathrm{pH} 3$ in $\mathrm{pH}$ adjustment tests for $D$. similis and at $\mathrm{pH} 9$ in $\mathrm{pH}$ graduated test and addition of EDTA for $C$. silvestrii, indicating ammonia, metals, and organic $\mathrm{pH}$-dependent compounds as possibly responsible for sediment toxicity (Table 3 ).

A chronic whole sediment TIE for $C$. silvestrii was carried out with the sediments from sites P1 and P2 of Pampulha reservoir in July 2014 and 2015, to determine ammonia, metals, or organic compounds (remediation experiments). The results presented in Table 4 showed an increase in reproduction of $C$. silvestrii after addition of zeolite resin and activated carbon (Tukey test $=3.53, p<0.05$ ), and the reduction of toxicity indicated that toxicity was caused by organic compounds (site P2) and ammonia (site P1).

\section{Barra Bonita and Salto Grande reservoirs}

For Barra Bonita TIE phase I, the values obtained for 48-h $\mathrm{EC}_{50}$ in the toxicity tests with elutriate performed with C. dubia before and after the TIE steps are presented in Table 5. Toxicity was totally removed after graduation $\mathrm{pH}$ tests at pH 6 and 9, addition of EDTA, and aeration tests in $\mathrm{pH} 3$ and $\mathrm{pH}$ 11. In the case of Salto Grande, according to the values obtained for $48-\mathrm{h} \mathrm{EC}_{50}$ in the toxicity tests performed with $C$. dubia, before and after the TIE steps, toxicity was removed after graduated at $\mathrm{pH} 6,7$, and 9, filtration in $\mathrm{pH}$ 11/7 and extraction in C18 column (Table 5).

The solubilization of the sediment caused a strong acidification of the sample ( $\mathrm{pH} 3.2$ ), and in this condition the toxicity remained constant, independent of the TIE manipulations. After correction to $\mathrm{pH} 7$, the toxicity was reduced after filtration at $\mathrm{pH} \mathrm{11,} \mathrm{extraction} \mathrm{in} \mathrm{C} 18$ column at $\mathrm{pH} 9$ (without recovering in the methanol extract), and $\mathrm{pH}$ gradient test at pH 7 (NT) and pH 9 (48-h $\mathrm{EC}_{50}=44.5 \%$ ) (Table 5). 
Fig. 3 Percentage of mobile Daphnia similis during exposure to sub-surface raw water of Pampulha reservoir (site P1) and after transfer to culture water

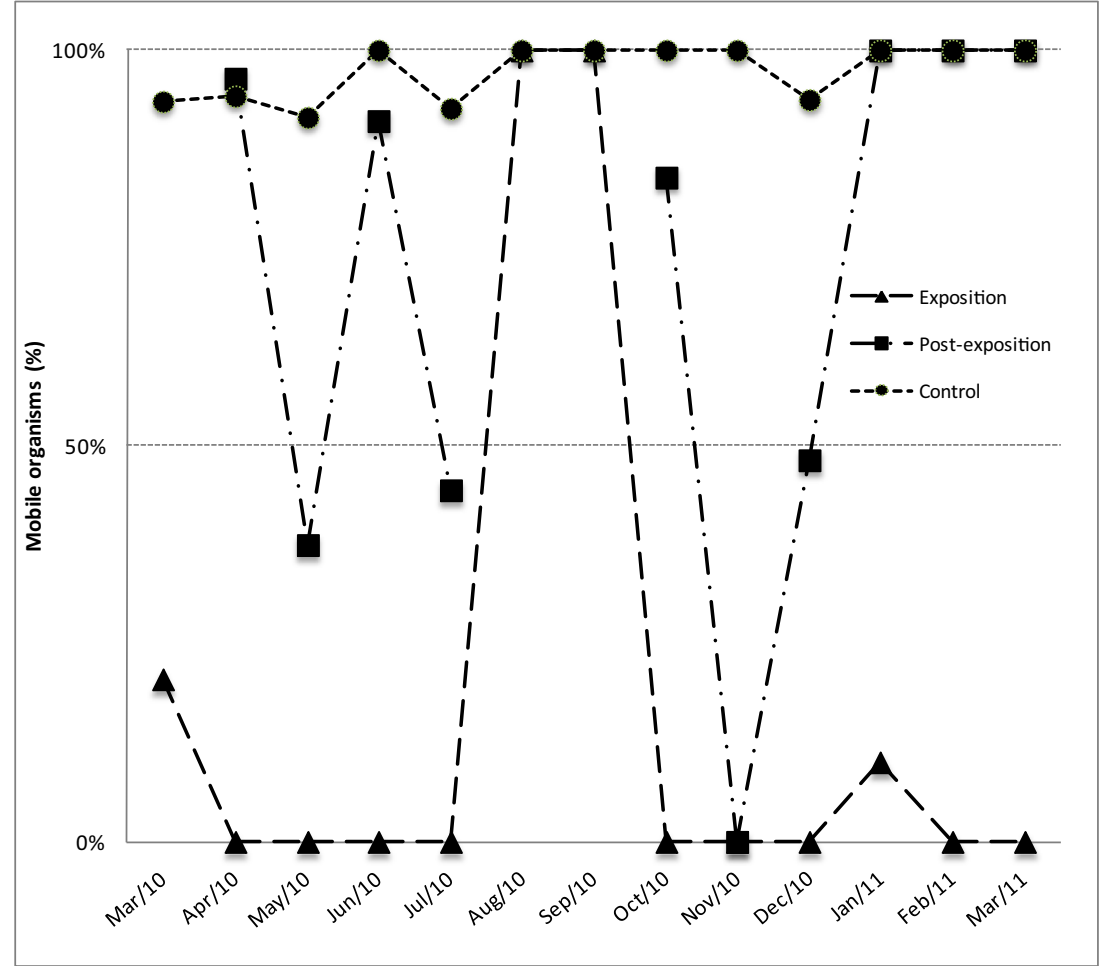

\section{TIE_phase II/III}

Table 6 presents the analysis of SEM and AVS and their ratios for Barra Bonita and Salto Grande reservoirs (TIE phase II). Nickel and zinc could be responsible for the toxicity of Barra Bonita sediment at sampling site, once their SEM/AVS ratios were higher than 1. For Salto Grande, none of the metals could be responsible for the toxicity of the sampling site, once their SEM/AVS ratios were lower than 1 .

The total ammonia concentration detected in the sediment elutriate fractions of Salto Grande was $3.2 \mathrm{mg} \mathrm{L}^{-1}$ (Table 7). To confirm ammonia as the compound responsible for the
Fig. 4 Percentage of mobile Daphnia laevis during exposure to sub-surface raw water of Pampulha reservoir (site P1) and after transfer to culture water (post-exposition)

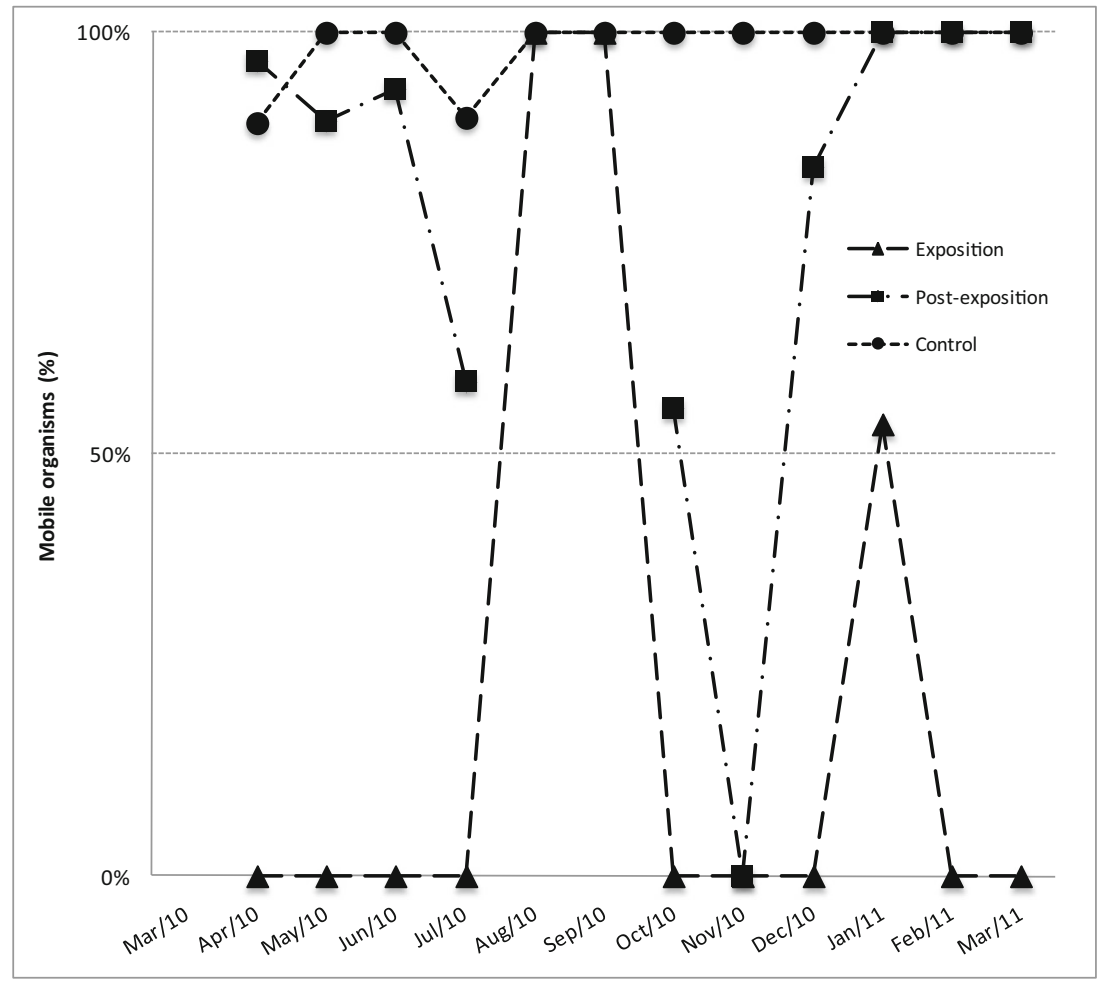




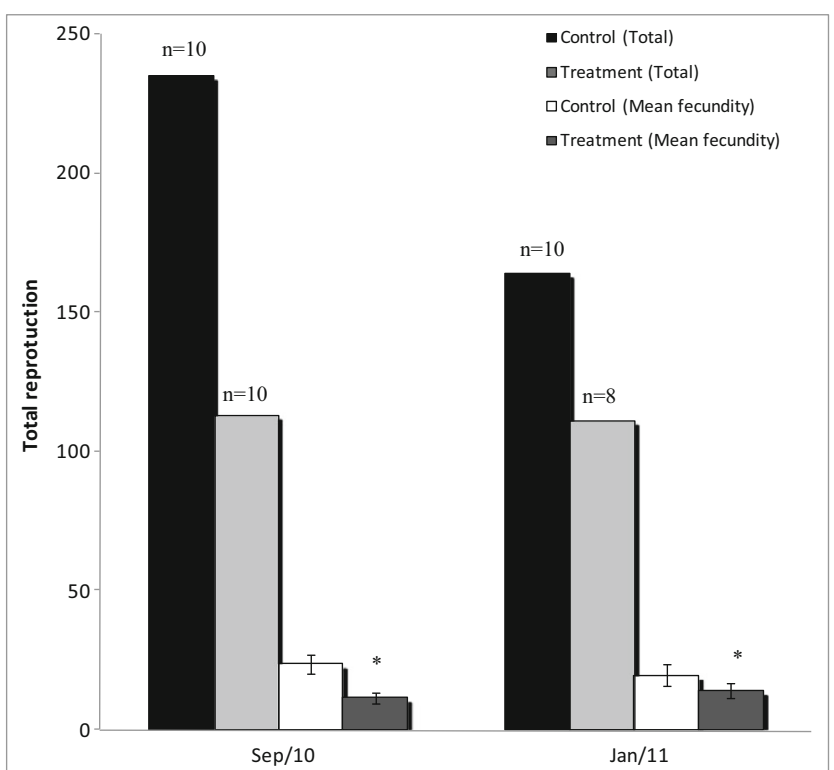

Fig. 5 Total neonates and mean fecundity of Ceriodaphnia silvestrii in chronic toxicity tests for sub-surface raw water carried out in September 2010 and January 2011 (asterisk: statistical differences between treatment and control, $p<0.05$ )

toxicity, the solubilized fractions were treated with zeolite resin. Ammonia concentration after contact with the resin was $2.2 \mathrm{~m} \mathrm{~L} \mathrm{~L}^{-1}$, corresponding to a reduction of about $32 \%$, compared to the initial concentration $\left(3.2 \mathrm{mg} \mathrm{L}^{-1}\right)$.

\section{Discussion}

\section{Water pollution in tropical reservoirs-an overview}

Water is such an essential resource that nowadays its quality and conservation are perhaps one the greatest challenges of the twenty-first century (Western and Pearl 1989; Tundisi 2003). Water pollution became a widespread phenomenon in the tropics due to the exponential population growth and jeopardizing anthropic activities which more and more compromises water quality and multiple uses of water resources.

Tropical reservoirs are among the water bodies with accelerated rates of degradation, both qualitative and quantitative, being presently a subject of great concern, since neither advanced technology nor economical resources will possibly allow their societies to cope with the dimension of problems to be generated by water scarcity (Wetzel 1991; Tundisi 2003; Vörösmarty et al. 2005). They are in most cases water bodies for multiple uses simultaneously serving urban and rural water supply, irrigation, hydroelectricity, and aquaculture (Brasil 2005), taking also into account that eutrophication and contamination of freshwaters affect biodiversity (Tundisi et al. 1998; Vörösmarty et al. 2010; Robin et al. 2013) as well as human health (Pouria et al. 1998; Azevedo et al. 2002; Giannuzzi et al. 2011).
Such problems become more evident in Southeast Brazil, considering that the reservoirs selected for this work are located in São Francisco and Paraná River basins, regions of highest population density and greatest industrial and agriculture activities. Urban reservoirs are more directly exposed to severe water and sediment pollution and reservoirs downstream can be affected by water quality of upstream reservoirs (Tundisi 1993, 2001). In order to attend initial purposes for their creation, the conservation of water resource quantity and quality is a basic necessity, although representing a big challenge (Tundisi 2003).

The results obtained and discussed subsequently constitute one such attempt.

\section{Pollutants and toxicity evaluation of Pampulha reservoir} water

This urban reservoir constructed for public water supply and recreation in the 1960s stopped providing such ecosystem services after no more than a decade, receiving domestic and industrial pollution there on. Analyses of water samples from Pampulha reservoir in 1998 (Tôrres 1999; Rietzler et al. 2001; Beato et al. 2003; Pinto-Coelho et al. 2003) and 10 years later (Sales 2009) showed that there was considerable increase in the concentration of metals after a decade.

Most metals present in the sediments, mainly copper, zinc, and iron, were much above the limits established by our National Environmental Agency (Brasil 2005). High iron concentrations are probably related to the eutrophic condition. Anoxic conditions increase the solubility of this metal and the release of sediment bound phosphate, boosting cyanobacteria bloom development and toxin release, leading to the vicious circle of toxicity and accelerated water and sediment quality degradation.

Our results from ecotoxicological tests evidenced loss of water quality in the sub-superficial layer of Pampulha reservoir since acute toxicity on $D$. similis and $D$. laevis were found in most experiments carried out in the years 2010 and 2011. Cyanobacterial blooms in that period were dominated by C. raciborskii and Planktothrix isothrix, which occurred throughout 2010 (Figueredo, personal communication), except in August, coincidently a period in which our monitoring showed no toxic effects for any tested organism.

Nevertheless, tested specimens did recover from immobility after being transferred to non-toxic culture water in the post-exposition experiments, in average $88 \%$ for $D$. similis and $91 \%$ for $D$. laevis indicating similar sensitivity for both species. Considering that $D$. laevis is an indigenous species occurring in Pampulha reservoir, its use as a test organism must be recommended. Moreover, our results confirmed the existence of neurotoxic effects in both cases, probably related to cyanobacteria present, $C$. raciborskii and $P$. isothrix. These two species are known to be potentially toxic, causing 


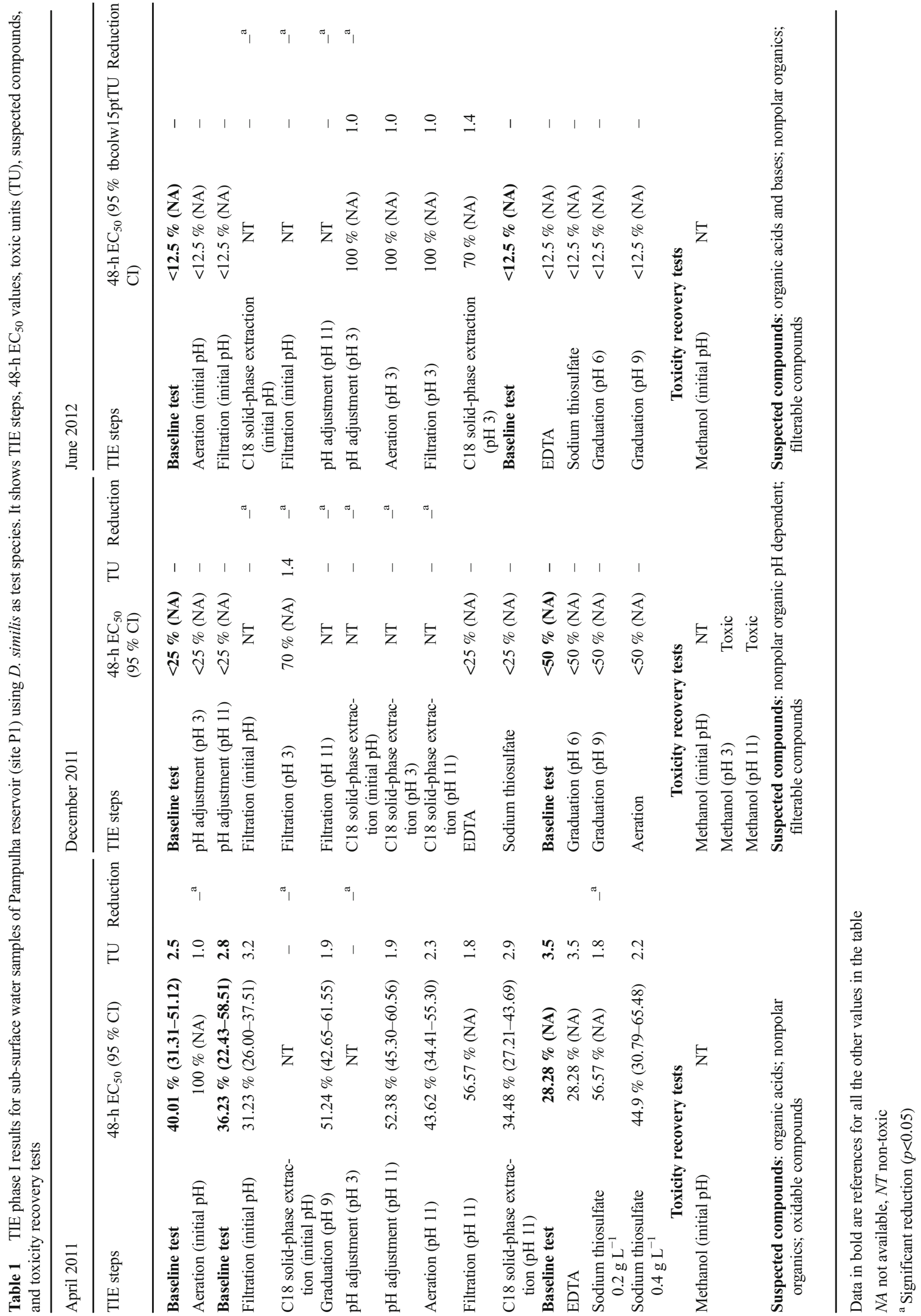


Table 2 TIE phase I results for sub-surface water samples of the final compartment of Pampulha reservoir using D. similis as test species

\begin{tabular}{|c|c|c|c|c|c|c|c|}
\hline \multicolumn{4}{|l|}{ April 2011} & \multicolumn{4}{|l|}{ May-June 2014} \\
\hline TIE steps & $48-\mathrm{EC}_{50}(95 \% \mathrm{CI})$ & $\mathrm{TU}$ & Reduction & TIE steps & $48-\mathrm{h} \mathrm{EC}{ }_{50}(95 \% \mathrm{CI})$ & $\mathrm{TU}$ & Reduction \\
\hline Baseline test & $72.48 \%$ (NA) & 1.4 & & Baseline test $1 \mathrm{~m}$ & $100 \%$ (NA) & 1.0 & \\
\hline Aeration & $61.56 \%(51.66-73.36)$ & 1.6 & & $\mathrm{pH}$ adjustment (pH 3) & NT & - & $-^{\mathrm{a}}$ \\
\hline $\begin{array}{l}\text { C18 solid-phase extraction } \\
\text { (initial } \mathrm{pH})\end{array}$ & NT & - & & pH adjustment (pH 11) & NT & - & $-^{\mathrm{a}}$ \\
\hline Baseline test & $56.57 \%$ (NA) & 1.8 & & Filtration (initial pH) & NT & - & $-^{\mathrm{a}}$ \\
\hline Filtration (initial $\mathrm{pH}$ ) & $28.95 \%(\mathrm{NA})$ & 3.5 & $-{ }^{\mathrm{a}}$ & $\mathrm{C} 18$ solid-phase extraction (initial $\mathrm{pH}$ ) & NT & - & $-^{\mathrm{a}}$ \\
\hline Graduation (pH 9) & $56.57 \%$ (NA) & 1.8 & & Baseline test $5 \mathrm{~m}$ & $100 \%$ (NA) & 1.0 & \\
\hline $\mathrm{pH}$ adjustment ( $\mathrm{pH} 3$ ) & $59.44 \%$ (NA) & 1.7 & & $\mathrm{pH}$ adjustment (pH 3) & NT & - & $-^{\mathrm{a}}$ \\
\hline Filtration ( $\mathrm{pH} 3$ ) & $28.28 \%$ (NA) & 3.5 & $-^{\mathrm{a}}$ & pH adjustment (pH 11) & NT & - & $-^{\mathrm{a}}$ \\
\hline $\begin{array}{l}\text { C18 solid-phase extraction } \\
(\mathrm{pH} \mathrm{3)}\end{array}$ & $23.78 \%$ (NA) & 4.2 & $-^{\mathrm{a}}$ & Filtration (initial pH) & NT & - & $-{ }^{\mathrm{a}}$ \\
\hline $\mathrm{pH}$ adjustment (pH 11) & $47.57 \%(38.47-58.82)$ & 2.1 & & C18 solid-phase extraction (initial $\mathrm{pH}$ ) & NT & - & $-^{\mathrm{a}}$ \\
\hline Aeration (pH 11) & $100 \%(\mathrm{NA})$ & 1.0 & $-{ }^{\mathrm{a}}$ & Baseline test $10 \mathrm{~m}$ & $100 \%$ (NA) & 1.0 & \\
\hline Filtration (pH 11) & $56.57 \%$ (NA) & 1.8 & & $\mathrm{pH}$ adjustment ( $\mathrm{pH} 3$ ) & NT & - & $-{ }^{\mathrm{a}}$ \\
\hline $\begin{array}{l}\text { C18 solid-phase extraction } \\
(\mathrm{pH} 9)\end{array}$ & $56.57 \%$ (NA) & 1.8 & & $\mathrm{pH}$ adjustment ( $\mathrm{pH} 11)$ & NT & - & $-^{\mathrm{a}}$ \\
\hline EDTA & $56.57 \%(\mathrm{NA})$ & 1.8 & & Filtration (initial pH) & NT & - & $-^{\mathrm{a}}$ \\
\hline \multirow[t]{2}{*}{ Sodium thiosulfate } & $56.57 \%(\mathrm{NA})$ & 1.8 & & $\mathrm{C} 18$ solid-phase extraction (initial $\mathrm{pH}$ ) & NT & - & $-^{\mathrm{a}}$ \\
\hline & & & & EDTA $10 \mathrm{~m}$ & $100 \%$ (NA) & 1.0 & \\
\hline \multicolumn{3}{|c|}{ Toxicity recovery tests } & \multicolumn{5}{|c|}{ Toxicity recovery tests } \\
\hline Methanol (initial pH) & NT & & & Methanol (initial pH) $1 \mathrm{M}$ & NT & & \\
\hline \multirow[t]{2}{*}{ Methanol (pH 3) } & NT & & & Methanol (initial pH) $5 \mathrm{M}$ & NT & & \\
\hline & & & & Methanol (initial $\mathrm{pH}$ ) $10 \mathrm{M}$ & NT & & \\
\hline
\end{tabular}

Suspected compounds: nonpolar organics; volatile compounds

Suspected compounds: organic acids and bases; nonpolar organics; filterable compounds

TIE steps, 48-h $\mathrm{EC}_{50}$ values, toxic units (TU), suspected compounds, and toxicity recovery tests are shown. Data in bold are references for all the other values in the table

$N A$ not available, $N T$ non-toxic

${ }^{\mathrm{a}}$ Significant reduction $(p<0.05)$

neurotoxic effects on zooplankton organisms (Ferrão-Filho et al. 2010; Silva 2012; Restani and Fonseca 2014).

A similar recovery from exposure to a bloom of toxic cyanobacteria was obtained for the tropical cladocerans Daphnia gessneri and Moina micrura when exposed to raw water of Funil reservoir (Rio de Janeiro State, Brazil) containing a bloom of $C$. raciborskii strain, a STX producer. Changes in the swimming behavior and recovery in culture water are usually indicative of neurotoxic effects (Ferrão-Filho et al. 2007, 2008, 2014).

The occurrence of Cyanobacteria toxins in eutrophic tropical reservoirs is nowadays a matter of great concern for both freshwater biota protection considering that saxitoxins and microcystins can cause a decrease in survival and reproduction of cladocerans (Ferrão-Filho et al. 2009) and for human health (Pouria et al. 1998; Azevedo et al. 2002; Dorr et al. 2010; Giannuzzi et al. 2011; Mowe et al. 2015).

Saxitoxins detected by ELISA analyses in Pampulha reservoir water by Jardim et al. (2010) at concentrations of $0.34 \mu \mathrm{g}$ Eq STX L L ${ }^{-1}$ can be considered enough to cause acute toxic effects on cladocerans. Thus, the concentration of STX found in the present study $(2.49 \mu \mathrm{g} \mathrm{Eq}$ $\mathrm{STX} \mathrm{L}^{-1}$ ) for Pampulha reservoir water was much higher than the one previously recorded by Jardim et al. (2010) and close to the highest values found by Ferrão-Filho et al. (2010) at Funil reservoir (between 0.3 and $3.0 \mu \mathrm{g} \mathrm{Eq} \mathrm{STX} \mathrm{L}{ }^{-1}$ ), which can cause immediate death of cladocerans in nature.

Moreover, such concentration is close to the maximum limit established by our legislation (Regulation 2914/2011)

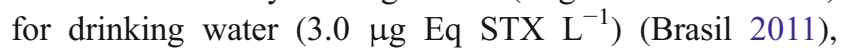
therefore preventing its use for water supply, direct recreation, and even irrigation. The same was observed for microcystin concentration $\left(183.0 \mu \mathrm{g} \mathrm{L}^{-1}\right)$ from the second water TIE performed for Pampulha reservoir, which is much higher than the limit permitted by legislation in terms of potability (1.0 $\mu \mathrm{g} \mathrm{L}^{-1} \mathrm{MC}$ ), thus compromising the main use of reservoir water as initially planned. 
Table 3 TIE phase I results for pore water samples of Pampulha reservoir using Daphnia similis and Ceriodaphnia silvestrii as test species in June 2012

\begin{tabular}{|c|c|c|c|c|c|c|c|}
\hline \multirow[t]{2}{*}{ TIE steps } & \multicolumn{3}{|l|}{ D. similis } & \multirow[t]{2}{*}{ TIE steps } & \multicolumn{3}{|l|}{ C. silvestrii } \\
\hline & $48-\mathrm{ECC}_{50}(95 \% \mathrm{CI})$ & $\mathrm{TU}$ & Reduction & & $48-\mathrm{EC}_{50}(95 \% \mathrm{CI})$ & $\mathrm{TU}$ & Reduction \\
\hline Baseline test & $74.58 \%$ (NA) & 1.3 & \multirow{6}{*}{$-^{\mathrm{a}}$} & Baseline test & $22.19 \%(16.89-29.15)$ & 4.5 & \multirow{6}{*}{$-{ }^{\mathrm{a}}$} \\
\hline Graduation (pH 6) & NT & - & & Graduation (pH 6) & $26.79 \%(21.62-33.21)$ & 3.7 & \\
\hline Graduation (pH 9) & $70.71 \%(\mathrm{NA})$ & 1.4 & & Graduation (pH 9) & $12.5 \%$ (NA) & 8.0 & \\
\hline Aeration (initial pH) & $70.71 \%$ (NA) & 1.4 & & Aeration (initial pH) & $<12.5 \%$ (NA) & - & \\
\hline Filtration (initial pH) & $70.71 \%(\mathrm{NA})$ & 1.4 & & Filtration (initial pH) & $25 \%$ (NA) & 4.0 & \\
\hline $\begin{array}{l}\text { C18 solid-phase extraction } \\
\text { (initial } \mathrm{pH})\end{array}$ & $70.71 \%(\mathrm{NA})$ & 1.4 & & $\begin{array}{l}\text { C18 solid-phase extraction } \\
\text { (initial } \mathrm{pH})\end{array}$ & $25 \%$ (NA) & 4.0 & \\
\hline Baseline test & $67.31 \%(61.33-73.87)$ & 1.5 & \multirow{4}{*}{ PR } & Baseline test & $32.99 \%(28.92-37.62)$ & 3.0 & \multirow{6}{*}{ PR } \\
\hline $\mathrm{pH}$ adjustment (pH 11) & $86.6 \%(82.52-90.88)$ & 1.2 & & pH adjustment (pH 3) & $50 \%$ (NA) & 2.0 & \\
\hline Filtration (pH 11) & $61.24 \%(57.21-65.55)$ & 1.6 & & Filtration ( $\mathrm{pH}$ 3) & $<12.5 \%(\mathrm{NA})$ & - & \\
\hline Aeration (pH 11) & $88.4 \%(82.58-94.64)$ & 1.1 & & Aeration ( $\mathrm{pH} 3$ ) & $35.36 \%(16.55-75.55)$ & 2.8 & \\
\hline pH adjustment ( $\mathrm{pH} 3$ ) & NT & - & \multirow[t]{7}{*}{$-^{\mathrm{a}}$} & Baseline test & $32.02 \%(28.25-36.30)$ & 3.1 & \\
\hline Baseline test & $73.49 \%$ (NA) & 1.4 & & $\mathrm{pH}$ adjustment ( $\mathrm{pH} 11)$ & $25.29 \%(21.15-30.24)$ & 3.9 & \\
\hline EDTA & $67.41 \%(52.67-86.28)$ & 1.5 & & Filtration (pH 11) & $35.36 \%(\mathrm{NA})$ & 2.8 & \multirow{5}{*}{$-{ }^{\mathrm{a}}$} \\
\hline \multirow[t]{4}{*}{ Sodium thiosulfate } & $73.49 \%(\mathrm{NA})$ & 1.4 & & Aeration (pH 11) & $35.36 \%(\mathrm{NA})$ & 2.8 & \\
\hline & & & & Baseline test & $12.5 \%(\mathrm{NA})$ & 8.0 & \\
\hline & & & & EDTA & 26,29 , and $31.5 \%$ & - & \\
\hline & & & & Sodium thiosulfate & $12.5 \%$ (NA) & 8.0 & \\
\hline \multicolumn{4}{|c|}{ Suspected compounds: ammonia; acid organics } & \multicolumn{4}{|c|}{ Suspected compounds: metals; acid organic } \\
\hline
\end{tabular}

TIE steps, 48-h $\mathrm{EC}_{50}$ values with confidence intervals (CI), toxic units (TU), and suspected compounds are shown. Data in bold are references for all the other values

$N A$ not available, $N T$ non-toxic, $P R$ partial reduction

${ }^{\mathrm{a}}$ Significant reduction $(p<0.05)$

The low toxicity of Pampulha water for $C$. silvestrii in the present study was possibly due to the fact that this small cladoceran is not able to ingest the filamentous potentially toxic cyanobacteria occurring in Pampulha reservoir. It was nevertheless affected once in acute toxicity tests and twice in chronic toxicity tests, what might indicate indirect exposure effects (possibly exudated cyanotoxins). This native species was found to be the most sensitive test organism in the study by Moreira et al. (2014). Ferrão-Filho et al. (2014) have also shown that small and medium cladocerans (like Ceriodaphnia richardi, D. gessneri, and Diaphanosoma spinulosum) are resistant to cyanobacteria. They also did not find negative effects on clutch size and total number of offspring when these cladocerans were exposed to $80 \mu \mathrm{g} \mathrm{L}^{-1}$ of C. raciborskii biomass. In contrast, in the same study, negative effects for those reproduction parameters were found for D. similis and M. micrura, at $12.5 \mathrm{ng}$ Eq STX L ${ }^{-1}$ showing that the vulnerability to the toxins was species-specific.

Many studies have evidenced the occurrence of cyanobacteria toxic strains in tropical and subtropical reservoirs, as well as in freshwater and saline lakes at different regions of Brazil (Sant'anna et al. 2008; Di Bernardo et al. 2010; Soares et al. 2013) as more and more water bodies become eutrophicated. Although Microcystis aeruginosa was widely the most representative among the toxic species (Azevedo et al. 1994; Matthiensen et al. 1999; Sant'anna et al. 2011; Bortoli et al. 2014), in the last decade, C. raciborskii is becoming frequent in many regions of the country, including the southeast region (Barbosa et al. 1999; Dellamano-Oliveira et al. 2008; Gomes et al. 2013).

Toxicity of Pampulha reservoir water assessed by TIE phase I procedures indicated organic and filterable compounds as responsible for most water toxicity. In considering $\mathrm{C} 18$ column extraction step, toxicity recovery tests carried out with eluted methanol extracts confirmed the presence of nonpolar organic compounds that are $\mathrm{pH}$ dependent. Although such compounds as well as the volatile and oxidable ones could not be confirmed by the absence of chemical analysis, aeration at $\mathrm{pH} 11$ could have indicated ammonia, considering that at this $\mathrm{pH}$ most ammonium is in the volatile form $\left(\mathrm{NH}_{3}\right)$. This step also indicated surfactants, commonly found in sanitary and industrial effluent waters.

At initial $\mathrm{pH}$, there was no toxicity recovering in methanol extracts, in any of the two sampled sites, indicating that $\mathrm{C} 18$ column worked as a filter, therefore indicating 
Table 4 Chronic TIE results for Ceriodaphnia silvestrii with addition of zeolite resin and activated carbon to whole sediment samples from sites P1 and $\mathrm{P} 2$ of Pampulha reservoir in July of 2014 and 2015

asignificant increase $(p<0.05)$

\begin{tabular}{|c|c|c|c|c|}
\hline Sampling period & Treatment & $\begin{array}{l}\text { Neonates/female } \\
\text { (mean values) }\end{array}$ & Toxicity & Suspected compounds \\
\hline \multirow[t]{4}{*}{ July 2014} & Site P1 & 7.0 & & \multirow[t]{2}{*}{ Ammonia } \\
\hline & Site P1 + zeolite & $12.0^{\mathrm{a}}$ & PR & \\
\hline & Site P2 & 5.0 & & \multirow[t]{2}{*}{ Organic compounds } \\
\hline & Site $\mathrm{P} 2+$ activated carbon & $10.0^{\mathrm{a}}$ & PR & \\
\hline \multirow{2}{*}{ July 2015} & Site P2 & 4.0 & & \multirow[t]{2}{*}{ Organic compounds } \\
\hline & Site $\mathrm{P} 2+$ activated carbon & $9.2^{\mathrm{a}}$ & PR & \\
\hline
\end{tabular}

that the toxicity is related to filterable compounds. This was further confirmed by the filtration step, since the toxicity of all samples was removed after filtration and recovered in the extracts of sonicated filters.

The extracts had toxic effects on $D$. similis and on C. silvestrii. In this case, the water toxicity on $D$. similis was associated to ingestion of cyanobacteria cells and that on C. silvestrii to the toxins released by breaking of cells after sonication. Based on these results, toxicity to $D$. similis could be attributed to cyanobacteria cells as well as toxins, also corroborated in the third water TIE procedure for Pampulha reservoir, after elution from C18 column and STX quantification.

Ecotoxicological results obtained for Pampulha reservoir water match results obtained for other Brazilian reservoirs, such as Funil reservoir in Rio de Janeiro State (Ferrão-Filho et al. 2009) and Ibirité reservoir in Minas Gerais state (Rietzler et al. 2010; Matos et al. 2014). The study conducted in Ibirité reservoir confirmed cyanotoxins by $\mathrm{C} 18$ post-column test and its recuperation by methanol extraction from the column (Botta et al. 2010). Microcystins were detected and considered responsible for the toxicity to $D$. similis.

\section{Toxicity identification and evaluation for Pampulha reservoir sediments}

Sediment studies of Pampulha reservoir have shown that high inputs of pollutants along the years have resulted in acute and chronic toxicity on benthic and epibenthic organisms (Rietzler and Viegas 2002; Sales 2009; Braidotti 2014). This led us to investigate the contaminants involved.

TIE phase I results obtained indicated that the main toxicants for the pore water at point 1 were ammonia for $D$. similis (toxicity reduction on $\mathrm{pH} 6$ graduation test), metals for C. silvestrii (toxicity reduction on EDTA tests), and acid organic compounds for both species (toxicity reduction on $\mathrm{pH} 3$ adjustment). Toxicity reduction after $\mathrm{pH} 3$ adjustment could also indicate ammonia, considering that this compound is less toxic at low $\mathrm{pHs}$, reinforcing previous indication of its toxicity to $D$. similis.

Although these compounds have not been confirmed in phase II by chemical analysis, the treatment of whole sediment with resin zeolite and activated carbon (USEPA 2007) performed in 2014 and 2015 partially removed the chronic toxicity, reinforcing the suggestion that the toxicants were ammonia and organic compounds.

Phillips et al. (2006), when conducting a TIE study related with remediation using a nonpolar carbonaceous resin (Ambersorb 563®) in parallel with powered coconut charcoal (PCC), were able to confirm that sediment toxicity was caused by organic contaminants in an agricultural area on the central California coast. Both compounds were able to reduce bioavailability of organic contaminants. However, Ambersorb, unlike charcoal, could be isolated from the sediment, eluted with methanol, and tested for toxicity recovery. Thus, the significant toxicity observed by the authors in the dilution water spiked with methanol eluate confirmed toxicity caused by organic contaminants.

\section{Toxicity identification and evaluation for Barra Bonita reservoir sediments}

In the case of Barra Bonita reservoir, the toxicity reduction after aeration and adjustment/aeration steps in $\mathrm{pH} 11$ and $\mathrm{pH} 3$ indicated the presence of volatile or oxidable compounds with $\mathrm{pH}$-dependent toxicity, such as ammonia and $\mathrm{H}_{2} \mathrm{~S}$, contaminants commonly found in tropical reservoirs (Janke et al. 2011). However, the simultaneous reduction of toxicity at $\mathrm{pH} 6$ and $\mathrm{pH} 8$ in the $\mathrm{pH}$ gradient tests ruled out the presence of ammonia and hydrogen sulfide (USEPA 1991).

Metals can also be detected at $\mathrm{pH}$ graduation step, from 6 to 9 (USEPA 1991). Considering that lead and copper toxicity for $C$. dubia is higher at $\mathrm{pH}$ 6, while zinc, nickel, and cadmium are higher at $\mathrm{pH} 8$, the toxicity reduction after EDTA treatment and $\mathrm{pH}$ graduation tests $(\mathrm{pH} 6$ and $\mathrm{pH} 8.5)$ could be related to copper and/or plumb (pH 6) and nickel, zinc, and/or cadmium (pH 8).

The SEM, AVS, and their ratios showed metals in excess contrasted to sulfide, indicating toxicity of metals (non-biological criterion), thus confirming TIE results. Although only partial, the TIE carried out for the sediment of Barra Bonita reservoir indicated nickel and zinc as responsible for toxicity, which was then confirmed by metals/SVA ratio. 
Table 5 TIE phase I results for sediment elutriate samples of Barra Bonita and Salto Grande reservoirs using Ceriodaphnia dubia as test species

Barra Bonita

\begin{tabular}{lccc}
\hline TIE steps & 48-h EC50 (95\%CI) & TU & Reduction \\
\hline Initial test & $\mathbf{6 1 . 2 \%}(\mathbf{N A})$ & 1.6 & PR \\
Aeration (initial pH) & $100 \%(\mathrm{NA})$ & 1.0 & $*$ \\
Aeration (pH3) & $\mathrm{NT}$ & - & $*$ \\
Aeration (pH11) & $\mathrm{NT}$ & - & $*$ \\
Graduation (pH6) & $\mathrm{NT}$ & - & $*$ \\
Graduation (pH8) & $\mathrm{NT}$ & - & $*$
\end{tabular}

Suspected compounds: metals; volatile organics

$\mathrm{pH}$ dependent (pH3 and $\mathrm{pH} 11)$ : ammonia, sulfide

\section{Salto Grande}

TIE steps

Initial test (3.2)

Graduation (pH6)

Graduation (pH7)

Graduation (pH9)

Initial test (3.2)

Aeration (initial $\mathrm{pH}$ )

Filtration (initial $\mathrm{pH}$ )

$\mathrm{pH}$ adjustment ( $\mathrm{pH} 7)$

$\mathrm{pH}$ adjustment (pH11) (3.2)

Aeration (pH11) (3.2)

Baseline test

Filtration (pH11) (3.2)

Filtration (pH11) (7.0)

Baseline test (3.9)

C18 solid-phase extration (initialpH)

C18 solid-phase extration (pH9)

EDTA

Sodium Thiosulfate

\begin{tabular}{|c|c|c|}
\hline $48-\mathrm{EC}_{50}(95 \% \mathrm{CI})$ & $\mathrm{TU}$ & Reduction \\
\hline $22 \%(16.4-34.3)$ & 4.5 & \\
\hline $84 \%$ (NA) & 1.2 & * \\
\hline NT & $<1$ & $*$ \\
\hline \multicolumn{3}{|l|}{$44.5 \%(45.0-$} \\
\hline 69.7) & 2.2 & $*$ \\
\hline $22 \%(16.4-34.3)$ & 4.5 & \\
\hline $33 \%(28.3-37.8)$ & 3.0 & \\
\hline $32 \%(22.8-44.9)$ & 3.1 & \\
\hline NT & $<1$ & $*$ \\
\hline $31 \%(23.6-39.9)$ & 3.2 & \\
\hline $31 \%(23.6-39.9)$ & 3.2 & \\
\hline $33 \%(22.8-44.9)$ & 3.0 & \\
\hline $52 \%(39.3-68.1)$ & 1.9 & \\
\hline $100 \%$ & 1.0 & $*$ \\
\hline $53 \%(41.3-65.4)$ & 1.9 & \\
\hline $53 \%(41.3-65.4)$ & 1.9 & \\
\hline NT & $<1$ & $*$ \\
\hline $53 \%(41.3-65.4)$ & 1.9 & \\
\hline $53 \%(41.3-65.4)$ & 1.9 & \\
\hline
\end{tabular}

Suspected compounds: ammonia, acids, metals.

TIE steps, 48-h EC $\mathrm{E}_{50}$ values with confidence intervals (CI), toxic units (TU), and suspected compounds are shown. The data presented in bold are references for others results

$N A$ not available, $N T$ non-toxic, $P R$ partial reduction

${ }^{\text {a }}$ Significant reduction $(p<0.05)$

According to Sibley et al. (1996), the non-biological toxicity criterion provided by metals/SVA relationships (ratios) is based on two assumptions: (1) link between sulfides and cationic metals $\mathrm{Cd}, \mathrm{Cu}, \mathrm{Pb}, \mathrm{Ni}$, and $\mathrm{Zn}$ in terms of molarity is $(1: 1)$ and (2) affinity of these metals for sulfide-binding sites is stronger than that of iron, the latter usually associated to sulfides in aquatic environments. This provides a competitive advantage for metallic sulfide formation. Considering proportionality for sulfide formation, when ratio metal/SVA is lower than 1 , binding sites will be higher than metal quantities. 
Table 6 Concentrations $\left(\mu \mathrm{g} \mathrm{g}^{-1}\right)$ of simultaneously extracted metals (SEM) and acid-volatile sulfide (AVS) and their ratios $\left(\mu \mathrm{mol} \mathrm{g}^{-1}\right)$ in sediment elutriate fractions of Barra Bonita and Salto Grande reservoirs

\begin{tabular}{|c|c|c|c|c|c|c|}
\hline \multirow{2}{*}{$\begin{array}{c}\text { Barra Bonita } \\
\text { June/ } 2000\end{array}$} & \multicolumn{5}{|c|}{ Metals $\left(\mu g \mathrm{~g}^{-1}\right)$} & \multirow{2}{*}{$\frac{\text { AVS }}{\left(\mu \mathrm{g} \mathrm{g}^{-1}\right)}$} \\
\hline & Cadmium & Copper & Lead & Nickel & Zinc & \\
\hline & 0.87 & 192 & -- & 789.6 & 422.6 & 132 \\
\hline \multicolumn{7}{|c|}{ [SEM] / [AVS] } \\
\hline & Cadmium & Copper & Lead & Nickel & Zinc & \\
\hline & $<1$ & 0.73 & 0.92 & 1.7 & 2.3 & \\
\hline Salto Grande & \multicolumn{5}{|c|}{ Metals $\left(\mu \mathrm{g} \mathrm{g} \mathrm{g}^{-1}\right)$} & AVS \\
\hline \multirow{5}{*}{ October/ 2001} & Cadmium & Copper & Lead & Nickel & Zinc & $\left(\mu \mathrm{g} \mathrm{g}^{-1}\right)$ \\
\hline & $<\mathrm{LQ}$ & 32.96 & 78.8 & 12.1 & 11.5 & 1590 \\
\hline & \multicolumn{5}{|c|}{ [SEM] / [AVS] } & \\
\hline & Cadmium & Copper & Lead & Nickel & Zinc & \\
\hline & -0.001 & 0.01 & 0.008 & 0.04 & 0.0033 & \\
\hline
\end{tabular}

$[\mathrm{SEM}] / \mathrm{AVS}>1$ : toxic; $[\mathrm{SEM}] / \mathrm{AVS}<1$ : non-toxic

These will be all bound, thus not available and no toxicity is therefore expected. On the other hand, if the ratio is higher than 1 , there will be more metals than binding sites, meaning more metals in pore water and sediment toxicity. This was exactly the situation verified for Barra Bonita reservoir sediments.

\section{Toxicity identification and evaluation for Salto Grande reservoir sediments}

Regarding Salto Grande reservoir, the toxicity observed at $\mathrm{pH}$ 9 graduated test (48-h EC 50 of $44.5 \%$ ) suggested the presence of ammonia, which besides being a contaminant commonly found in aquatic environments (Russo 1995; Janke et al. 2011) is one of the most toxic ionic compounds at high $\mathrm{pH}$, due to the predominance of its unionized form $\left(\mathrm{NH}_{3}\right)$ which is more toxic than the cationic form $\left(\mathrm{NH}_{4}{ }^{+}\right)$(USEPA 1991). The observed decrease in toxicity after $\mathrm{pH}$ adjustment/aeration at $\mathrm{pH}$ 11 and return to $\mathrm{pH} 7$ reinforced this hypothesis.

The total ammonia concentration detected in the elutriate fractions of Salto Grande sediment was $3.2 \mathrm{mg} \mathrm{L}^{-1}$. Considering that at pH $936 \%$ of this ammonia should be $\mathrm{NH}_{3}$, the calculated concentration of $\mathrm{NH}_{3}$ in the sample would be $1.2 \mathrm{mg} \mathrm{L}^{-1}$. According to USEPA (1991) and Ankley et al. (1990), the 48-h $\mathrm{EC}_{50}$ for C. dubia ranges from 0.78 to
$2.88 \mathrm{mg} \mathrm{L}^{-1}$. Thus, the toxicity might be due to ammonia. Several studies have shown that the toxicity of sediment pore water or of elutriate of sediments is due to ammonia (Ankley et al. 1990; Ankley and Schubauer-Beringan 1995; Whiteman 1996; Van Sprang and Janssen 1997; Araujo et al. 2006).

The solubilized sediment fractions of Salto Grande treated with zeolite resin showed a toxicity reduction of $20 \%$ for the more concentrated sample (Table 7). Besides ammonia, the toxicity of Salto Grande sediment was therefore related to the physiological effects of acidity.

The toxicity reduction after filtration on $\mathrm{pH} 11$ and toxicity recovering after filters sonication at $\mathrm{pH} 3$ suggested the presence of metals. Although the treatment with EDTA did not change the toxicity of the elutriate fractions, the metals copper and zinc could be responsible for some of the sediment toxicity observed, once the concentrations detected in elutriate fractions (127.0-149.0 and 327.0-434.0 $\mu \mathrm{g} \mathrm{L}^{-1}$, respectively) were above or around the $\mathrm{EC}_{50}$ for Ceriodaphnia species (11.0-25.0 and $420.0 \mu \mathrm{g} \mathrm{L}^{-1}$, respectively). However, the sulfide present in the reservoir sediment acted as metal controller.

The results showed an excess of AVS in the sediment analyzed (Table 6), so that the metals present were not available and therefore non-toxic (Di Toro et al. 1992; Allen et al. 1993; Ankley 1996; Berry et al. 1996; Besser et al. 1996; Sibley
Table 7 Immobility (\%) of Ceriodaphnia dubia exposed to different sediment elutriate concentrations from Salto Grande reservoir, before and after treatment with zeolite resin

\begin{tabular}{|c|c|c|c|c|c|c|}
\hline \multirow{2}{*}{$\frac{\text { Sample features }}{\text { Sample concentration }(\%)}$} & \multicolumn{3}{|c|}{ Without zeolite } & \multicolumn{3}{|c|}{ With zeolite } \\
\hline & 100.0 & 50.0 & 25.0 & 100.0 & 50.0 & 25.0 \\
\hline Ammonia concentration $\left(\mathrm{mg} \mathrm{L}^{-1}\right)$ & 3.2 & 1.6 & 0.8 & 2.2 & 1.1 & 0.5 \\
\hline $\mathrm{pH}$ & 3.4 & 4.9 & 6.5 & 7.5 & 7.5 & 7.2 \\
\hline Immobility (\%) & 100.0 & 100.0 & 27.0 & 80.0 & 6.0 & 0 \\
\hline
\end{tabular}


et al. 1996; Wang and Chapman 1999). Likewise, the results obtained by Araujo et al. (2006) for Rasgão reservoir, SP, showed that, despite the relatively high concentrations of total metals, the ratio metal/SVA was lower than 1, and metals were not available. However, in acid conditions, metals can represent a risk of toxicity.

\section{Toxicity and the loss of water quality in tropical reservoirs}

In natural environments, the occurrence of low $\mathrm{pH}$ and metals constitutes a potential source of toxicity. There are many factors, natural or not, capable of changing the $\mathrm{pH}$ in lakes and reservoirs: dredging activities and humic and fulvic acid production via organic matter decomposition. These might be lethal to aquatic biota, directly or indirectly via metal toxicity. The tendency of sediments to produce acids depends on the balance between its acidproducing potential and its buffering capacity, represented respectively by the oxidation of sulfide and organic matter and by the carbonate content of the sediment (Calmano et al. 1993; Chuan et al. 1996). Changes in the oxygen content and redox potential caused by the solubilizing process in laboratory could also be responsible for lowering the $\mathrm{pH}$. It might simulate a phenomenon that may occur in natural environments, due to microbiological and chemical processes at the sediment-water interface or in the sediment itself.

Most pollutants of anthropogenic origin are absorbed by particles of organic matter and tend to accumulate in the sediment, leading to detrimental effects on species and communities in water and sediment (Burton et al. 2003). We have shown evidences, from toxicity experiments and from chemical analyses and TIE procedures, that Pampulha reservoir has been continuously exposed to eutrophication and contamination by different pollutants. Its water and sediment quality is deteriorated to such an extent that lethal and sub-lethal effects on sensitive native and non-native invertebrate species were repeatedly demonstrated.

To assess the full impact and find solutions to the problem of toxic cyanobacterial blooms in the water and persistent pollutants in the sediment, a long-term biological monitoring program using different techniques and a variety of test organisms should be undertaken, as recommended by Chapman and Hollert (2006) and Ingersoll et al. (2015).

In the present study, the TIEs performed with the sediment of the three reservoirs indicated organic compounds, ammonia, and metals as responsible for the toxicity of pore water, whole sediment, and elutriate. These results were similar to the results obtained by Ho and Burgess (2013), in a review including 36 peer-reviewed TIE studies from 67 sediments, performed in the last 20 years. The results summarized by the authors showed that the three most frequent classes of toxicants were organic compounds, cationic metals, and ammonia. Considering pore water studies of freshwater sediments, approximately $76 \%$ of all sediments had a non-ionic organic chemical, $57 \%$ had a cationic metal, and $24 \%$ had ammonia, singly or in some combination, while for whole sediment, $90 \%$ of all sediments tested had organic chemical toxicity, singly or in combination with another toxicant.

The findings that toxic compounds in the sediments of the reservoirs studied here do not greatly differ from those in temperate reservoirs indicate that trivial domestic and industrial wastes were involved. A positive aspect is that in this case it is possible to apply at least partially from the knowledge and experience developed for remediation of temperate water bodies (UNEP 2001a).

A major constraint for keeping water quality in tropical reservoirs, on the other hand, is the fact that eutrophication goes faster in tropical than in temperate regions (UNEP 2001b). Global climate changes may intensify sediment-water column exchanges leading to fast worsening of water quality of shallow reservoirs around the world (Jeppesen et al. 2014). Tropical countries must therefore have greater concern and urgently make much greater efforts in order to prevent further water and sediment pollution, especially in water bodies for water supply, considering that remediation is always more difficult and costly.

\section{Conclusions}

The toxicity of the water of Pampulha reservoir for sensitive species of invertebrates was experimentally demonstrated, evidencing the risk to aquatic biota and its relationship with toxic cyanobacteria in the reservoir.

Sediments of all three reservoirs, Pampulha, Barra Bonita, and Salto Grande, were found to be polluted and toxic to invertebrates. Toxicity identification and evaluation approach applied to water in Pampulha and to sediment of all three reservoirs indicated as main pollutants and most probable toxicant agents: ammonia in Pampulha and Salto Grande, organic compounds in Pampulha, and acidity in Salto Grande reservoir and metals in all reservoirs.

It is suggested that the toxicity and consequent loss of water and sediment quality in these tropical reservoirs are all related to one and same problem, accelerated eutrophication.

The treatment of Pampulha whole sediment with zeolite with specificity for ammonia and organic compounds reduced the sediment toxicity, representing a possible remediation tool.

For Barra Bonita, metals were found responsible for the toxicity detected in its sediments and the ratio of total metals to acid volatile sulfide confirmed this evidence. 
In the case of Salto Grande, besides acidity, ammonia may have also contributed to the toxicity. For metals, even present, the ratio of total metals to AVS indicated an excess of AVS and therefore the metals would not be available to cause toxic effects. However, the coupling of low $\mathrm{pH}$ and the presence of metals might be a potential factor of toxicity here.

Thus and again, the compounds and chemical toxicants present in the sediments evaluated are all related to the accelerated eutrophication and contamination.

Acknowledgments We would like to thank Dr. Ricardo Motta PintoCoelho for logistic support, Prof. Alessandra Giani for help with water sampling, Dr. Cleber Figueredo for confirming cyanobacteria identity on tested water samples, and Prof. Sandra Azevedo for cyanotoxin quantification.

\section{References}

ABNT-Associação Brasileira de Normas Técnicas (1995) NBR 12713-Ecotoxicologia aquática-Toxicidade aguda-Método de ensaio com Daphnia spp (Crustacea, Cladocera). ABNT, Rio de Janeiro, p 23

ABNT-Associação Brasileira de Normas Técnicas (2005) NBR 13373-Ecotoxicologia aquática-Toxicidade crônica-Método de ensaio com Ceriodaphnia spp (Crustacea, Cladocera). ABNT, Rio de Janeiro, $\mathrm{p} 12$

ABNT_Associação Brasileira de Normas Técnicas (2010) NBR 12713: 2004 -Ecotoxicologia aquática - Toxicidade aguda-Método de ensaio com Daphnia spp (Crustacea, Cladocera). ABNT, Rio de Janeiro, p 23

ABNT-Associação Brasileira de Normas Técnicas (2011) NBR 13373: 2011-Ecotoxicologia aquática-Toxicidade crônica-Método de ensaio com Ceriodaphnia spp (Crustacea, Cladocera). ABNT, Rio de Janeiro, $\mathrm{p} 12$

Allen HE, Fu G, Deng B (1993) Analysis of acid-volatile sulfide (AVS) and simultaneously extracted metals (SEM) for the estimation of potential toxicity in aquatic sediments. Environ Toxicol Chem 12: 2181-2186. doi:10.1002/etc.5620120812

Anderson BS, Phillips BM, Hunt JW, Clark SL, Voorhees JP, Tjeerdema RS, Casteline J, Stewart M, Crane D, Mekebri A (2010) Evaluation of methods to determine causes of sediment toxicity in San Diego Bay, California, USA. Ecotox Environ Safe 73(4):534-540. doi:10.1016/j.ecoenv.2010.01.007

Ankley GT (1996) Evaluation of metal/acid-volatile sulfide relationships in the prediction of metal bioaccumulation by benthic macroinvertebrates. Environ Toxicol Chem 15(12):2138-2146. doi:10.1002 /etc. 5620151209

Ankley GT, Schubauer-Beringan MK (1995) Background and overview of current sediment toxicity identification procedures. Aquat Ecosyst Health 4:133-419. doi:10.1007/BF00116649

Ankley GT, Katko A, Arthur JW (1990) Identification of ammonia as an important sediment-associated toxicant in the lower Fox River and Green Bay, Wisconsin. Environ Toxicol Chem 9:313-322. doi:10.1002/etc.5620090307

APHA - American Public Health Association; American Water Work Association; Water Pollution Control Federation (1992) Standard methods for the examination of water and wastewater, 18th edn. New York. $1268 \mathrm{p}$

Araujo RPA et al (2006) Application of toxicity identification evaluation to sediment in a highly contaminated water reservoir in southeastern Brazil. Environ Toxicol Chem 25(2):206-213. doi:10.1897/05-144R.1
Azevedo SMFO, Carmichael WW, Jochimsen EM, Rinehart KL, Lau S, Shaw GR, Eaglesham GK (2002) Human intoxication by microcystins during renal dialysis treatment in Caruaru-Brazil. Toxicology 181182(441-446). doi: 10.1016/S0300-483X(02)00491-2.

Azevedo SMFO, William ER, Carmichael WW, Namikoshi M (1994) First report of microcystins from a Brazilian isolate of the cyanobacterium Microcystis aeruginosa. J Appl Phycoll 6:261-265. doi:10.1007/BF02181936

Barbosa FAR, Padisák J, Espíndola ELG, Borics G, Rocha O (1999) The cascading reservoir continuum concept (CRCC) and its application to the river Tietê-basin, São Paulo State, Brazil. In: Tundisi JG, Straskraba M (eds) Theoretical reservoir ecology and its applications. Brazilian Academy of Sciences, International Institute of Ecology/ Backhuys Publishers, São Carlos 425-437p

Beato DAC, Medeiros MJ, Drews MGP, Dutra GM (2003) Urbans impacts in sub groundwaters-watershed Pampulha. Revista Águas Subterrâneas, Belo Horizonte 17p. (in Portuguese)

Berry WJ et al (1996) Predicting the toxicity of metal-spiked laboratory sediments using acid-volatile sulfide and interstitial water normalizations. Environ Toxicol Chem 15(12):2067-2079. doi:10.1002 /etc.5620151203

Besser JM, Ingersoll CG, Giesty JP (1996) Effects of spatial and temporal variation of acid-volattle sulfide on the bioavailability of copper and zinc in freshwater sediments. Environ Toxicol Chem 15(3):286293. doi:10.1002/etc. 5620150310

Besser JM et al (1998) Effect of zeolite on toxicity of ammonia in freshwater sediments: implications for toxicity identification evaluation procedures. Environ Toxicol Chem 17(11):2310-2317. doi:10.1002 /etc. 5620171123

Böhrer-Morel MB, Carvalho N, Capoleti C, Lameira V, Mamono P, Pires LB, Silva AM (2005) Use of autochtonous species of invertebrates in aquatic toxicity tests. Progress Report, Instituto de Pesquisas em Energia Nuclear, IPEN, pp 220-2004. 15p

Bortoli S, Oliveira-Silva D, Krüger T, Dörr FA, Colepicolo P, Volmer DA, Pinto E (2014) Growth and microcystin production of a Brazilian Microcystis aeruginosa strain (LTPNA 02) under different nutrient conditions. Rev bras farmacogn 24(4):389-398. doi:10.1016/j. bjp.2014.07.019

Botta CMR, Rietzler AC, Fonseca AL, Ribeiro MM, Martins FG, Yamada TM, Mozeto AA, Faria B (2010) Toxicity identification and evaluation as management tool of contaminated sediment from the Ibirité reservoir (MG, Brazil). In: ECOTOX - XI Congresso Brasileiro de Ecotoxicologia - Resumos, Bombinhas, SC. (In Portuguese)

Braidotti JC (2014) Studies in situ in the Pampulha reservoir, Minas Gerais. Master Thesis, Federal University of Minas Gerais. (in Portuguese)

Brasil. Ministério da Saúde, 2011. Portaria 2.914, de 12 de dezembro de 2011. Dispõe sobre os procedimentos de controle e de vigilância da qualidade da água para consumo humano e seu padrão de potabilidade. Diário Oficial da República Federativa do Brasil, Brasília, dez. $18 \mathrm{p}$

Brasil. Ministério do Meio Ambiente. Conselho Nacional do Meio Ambiente - CONAMA (2005) Dispõe sobre a classificação dos corpos de água e diretrizes ambientais para o seu enquadramento, bem como estabelece as condições e padrões de lançamento de efluentes, e dá outras providências. Resolução CONAMA n. 357, de 17 de março de 2005. Disponível em: http://www.mma.gov. br/port/conama/legiabre.cfm?codlegi=459. Accessed: 13 nov. 2010

Buratini SV, Aragão MA, Araujo RPA et al (2007) Toxicity identification evaluations in Baquirivu-Guaçu River. J Braz Soc Ecotoxicol 2(3): $257-262$

Burgess RM, Charles JB, Kuhn A, Ho KT, Patton LE, McGovern DG (1997) Development of a cation-exchange methodology for marine toxicity identification evaluation applications. Environ Toxicol Chem 16(6):1203-1211. doi:10.1002/etc.5620160615 
Burgess RM, Ho KT, Tagliabue MD, Kuhn A, Comeleo R, Comeleo P, Modica G, Morrison GE (1995) Toxicity characterization of an industrial and a municipal effluent discharging to the marine environment. Mar Pollut Bull 30(8):524-535. doi:10.1016/0025-326X(94)00242-2

Burton GA, Macpherson C (1995) Sediment toxicity issues and methods. In: Hoffman DJ, Rattner BA, Burton GA, Cairns Jr J (eds) Handbook of ecotoxicology. Lewis Publishers, Flórida 2-71p

Burton GA Jr, Denton DL, Ho K, Ireland DS (2003) Sediment toxicity testing: issues and methods. In: Hoffman DJ, Rattner BA, Burton AG, Cairns J (eds) Handbook of ecotoxicology, 2nd edn. Lewis Publishers, Washington 111-150p

Calmano W, Hong J, Forstner U (1993) Binding and mobilization of heavy metals in contaminated sediments affected by $\mathrm{pH}$ and redox potential. Water Sci Technol 28(8-9):223-235. doi:10.15480 1882.450

Calmano W, Hong J, Forstner U (1993) Binding and mobilization of heavy metals in contaminated sediments affected by $\mathrm{pH}$ and redox potential. Water Sci Technol 28(8-9):223-235. doi:10.15480 $/ 882.450$

Chan YK, Wong CK, Hsieh DPH, Ng SP, Lau TK, Wong PK (2003) Application of a toxicity identification evaluation for a sample of effluent discharged from a dyeing factory in Hong Kong. Environ Toxicol 18(5):312-316. doi:10.1002/tox.10130

Chapman PM, Hollert H (2006) Should the sediment triad become a tetrad, a pentad, or possibly a hexad? J Soils Sediments 6(1):4-8. doi:10.1065/jss2006.01.152

Chorus I (2001) Cyanotoxins: occurrence, causes, consequences. Springer, New York 357 pp

Chuan MC, Shu GY, Liu JC (1996) Solubility of heavy metals in a contaminated soil: effects of redox potential and $\mathrm{pH}$. Water Air Soil Poll 90:543-556. doi:10.1007/BF00282668

Codd GA (2000) Cyanobacteria toxins, the perception of water quality and the prioritisation of eutrophication control. Ecol Eng 16(1):5160. doi:10.1016/S0925-8574(00)00089-6

Cross K, Latorre C (2015) Which water for which use? Exploring water quality instruments in the context of a changing climate. Aquat Procedia 5:104-110. doi:10.1016/j.aqpro.2015.10.012

Davis JR, Koop K (2006) Eutrophication in Australian rivers, reservoirs and estuaries - a southern hemisphere perspective on the science and its implications. Hydrobiologia 559:23-76. doi:10.1007 /s10750-005-4429-2

Dellamano-Oliveira MJ, Vieira AAH, Rocha O, Colombo V, Sant'Anna CL (2008) Phytoplankton taxonomic composition and temporal changes in a tropical reservoir. Fund And Appl Limnol: Arch für Hydrobiologie 171(1):27-38. doi:10.1127/1863-9135/2008/0171-0027

Di Bernardo L, Minillo A, Dantas ADB (2010) Blooms of algae and cyanobacteria: their influences on water quality and technologies. Editora LDiBe Ltda, São Carlos in Portuguese

Di Toro DM et al (1992) Acid-volatile sulfide predicts the acute toxicity of cadmium and nickel in sediments. Envir Sci Tech 26(1):96-101. doi:10.1021/es00025a009

Dodson J (2010) Changing climates, earth systems and society. Springer, Dordrecht $245 \mathrm{p}$

Dorr FA, Pinto E, Soares RM, Azevedo SMFO (2010) Microcystins in south American aquatic ecosystems: occurrence, toxicity and toxicological assays. Toxicon 56:1247-1256. doi:10.1016/j. toxicon.2010.03.018

Downing JA, Watson SB, Mc Cauley E (2001) Predicting cyanobacteria dominance in lakes. Can J Fish Aquat Sci 589:1905-1908. doi:10.1139/f01-143

Ferrão-Filho AS, Costa SM, Ribeiro MGL, Azevedo SMFO (2008) Effects of a saxitoxin producer strain of Cylindrospermopsis raciborskii (cyanobacteria) on the swimming movements of cladocerans. Environ Toxicol 23:161-168. doi:10.1002/tox.20320

Ferrão-Filho AS, Cunha R, Magalhães VF, Soares MCS, Baptista DF (2007) Evaluation of sub-lethal toxicity of cyanobacteria on the swimming activity of aquatic organisms by image analysis. J Braz Soc Ecotoxicol 2(2):93-100. doi:10.5132/jbse.2007.02.001

Ferrão-Filho AS, Galvão LEC, Magalhães VF (2014) Differential susceptibility of cladoceran species to a saxitoxin-producer strain of Cylindrospermopsis raciborskii (cyanobacteria). Ecotox Environ Contam 9:33-41. doi:10.5132/eec.2014.01.005

Ferrão-Filho AS, Soares MCS, Magalhães VF, Azevedo SMFO (2009) Biomonitoring of cyanotoxins in two tropical reservoirs by cladoceran toxicity bioassays. Ecotoxicol Environ Safe 72:479-489. doi:10.1016/j.ecoenv.2008.02.002

Ferrão-Filho AS, Soares MCS, Magalhães VF, Azevedo SMFO (2010) A rapid bioassay for detecting saxitoxins using a Daphnia acute toxicity test. Environ Pollut 158:2084-2093. doi:10.1016/j. envpol.2010.03.007

Giannuzzi L, Sedan D, Echenique R, Adrinolo D (2011) An acute case of intoxication with cyanobacteria and cyanotoxins in recreational water in Salto Grande dam, Argentina. Mar Drug 9(11):2164-2175. doi:10.3390/md9112164

Giesy JP, Rosiu CJ, Graney RL (1990) Benthic invertebrate bioassays with toxic sediment and pore water. Environ Toxicol Chem 9:233248. doi:10.1002/etc.5620090214

Giesy JP et al (1988) A comparison of three sediment bioassay method using Detroit river sediments. Environ Toxicol Chem 7:483-498. doi:10.1002/etc.5620070608

Gomes AMA, Marinho MM, Azevedo SMFO (2013) Which factors are related to the success of Cylindrospermopsis raciborskii in Brazilian aquatic systems? 73-94p. In: Ferrão-Filho AS (ed) Cyanobacteria: ecology, toxicology and management. Nova Publishers, New York

Greenstein DJ, Bay SM, Young DL, Asato S, Maruya KA, Lao W (2014) The use of sediment toxicity identification evaluation methods to evaluate clean up targets in an urban estuary. Integr Enviro Assess Manage 10(2):260-268. doi:10.1002/ieam

Gulley D (1996) Toxstat 3.5, West Inc. University of Wyoming, Cheyenne

Hamilton MA, Russo RC, Thurfton RB (1977) Trimmed SpearmanKarber methods for estimating median lethal concentration in toxicity biossay. Environ Sci Technol 11:714-719. doi:10.1021/es60130 a004

Ho KT, Burgess RM (2013) What's causing toxicity in sediments? Results of 20 years of toxicity identification and evaluation. Environ Toxicol Chem 32(11):2424-2432. doi:10.1002/etc.2359

Ho KT, Burgess RM, Pelletier MC et al (2002) An overview of toxicant identification in sediments and dredged materials. Mar Pollut Bull 44:286-293. doi:10.1016/S0025-326X(01)00251-X

Hoffman DJ, Partner BA, Burton GA, Cairns J (2002) Handbook of ecotoxicology. Lewis Publishers, Flórida

Huszar VLM, Silva LHS, Marinho MM, Domingos P, Sant'Anna CL (2000) Cyanoprokaryote assemblages in eight productive tropical Brazilian waters. In: Reynolds CS, Dokulil M, Padisák J (eds) The trophic spectrum revisited: the influence of trophic state on the assembly of phytoplankton communities. Developments in Hydrobiology. Hydrobiologia. Kluwer Academic Publishers, Dordrecht, p 67-77

Ingersoll CG, Kunz JL, Hughes JP, Wang N, Ireland DS, Mount DR, Hockett JR, Valenti TW (2015) Relative sensitivity of an amphipod Hyalella azteca, a midge Chironomus dilutus, and a unionid mussel Lampsilis siliquoidea to a toxic sediment. Environ Toxicol Chem 34(5):1134-1144. doi:10.1002/etc.2909

Janke H, Yamada TM, Beraldo DAS, Botta CMR, Nascimento MRL, Mozeto AA (2011) Assessment of the acute toxicity of eutrophic sediments after the addition of calcium nitrate (Ibirité reservoir, Minas Gerais-SE Brazil): initial laboratory experiments. Braz J Biol 71(4):903-914. doi:10.1590/S1519-69842011000500011

Jardim FA, Carvalho LS, Couto PGP (2010) Toxicity and ecology of Cylindrospermopsis raciborskii (Cyanobacteria) isolated from 
urban reservoir. X Simpósio Ítalo-brasileiro de Engenharia Sanitária e Ambiental. ABES-ANDIS, Maceió in Portuguese

Jeppesen E, Meerhoff M, Davidson TA, Trolle D, Sondergaar M et al (2014) Climate change impacts on lakes: an integrated ecological perspective based on a multi-faceted approach, with special focus on shallow lakes. J Limnol 73(1):88-111. doi:10.4081 /jlimnol.2014.844

Kuhl AM, Rocha CLMSC, Espíndola ELG, Lansac-Tôha FA (2010) Rural and urban streams: anthropogenic influences and impacts on water and sediment quality. Int Rev Hydrobiol 95(3):260-272. doi:10.1002/iroh.200911190

Larouque-Tobler I, Laurion I, Moschen R, Stewart M (2010) Climate and lacustrine ecosystems. In: Dodson J (ed) Changing climates, earth systems and society. Springer, Dordrecht 123-160p

Li H, Murphy T, Guo J, Parr T, Nalewajko C (2009) Iron-stimulated growth and microcystin production of Microcystis novacekii UAM 250. Limnologica 39(3):255-259. doi:10.1016/j.limno.2008.08.002

Maltby L, Boxall ABA, Forrow DM, Calow P, Betton CL (1995) The effects of motorway runoff on freshwater ecosystems: II identifying major toxicants. Environ Toxicol Chem 14(6):1093-1101. doi:10.1002/etc.5620140621

Manahan SE (2013) Fundamentals of environmental and toxicological chemistry: sustainable science, 4th edn. CRC Press, New York 590 p

Matos MF, Botta CMR, Fonseca AL (2014) Toxicity identification evaluation (phase I) of water and sediment samples from a tropical reservoir contaminated with industrial and domestic effluents. Environ Monit Assess 186:7999-8006. doi:10.1007/s10661-0143982-4

Matthiensen A, Yunes JS, Codd GA (1999) Ocorrência, distribuição e toxicidade de cianobactérias no estuário da Lagoa dos Patos, RS. Rev Bras Biol 59(3):361-376. doi:10.1590 /S003471081999000300002

Molica R, Azevedo SMFO (2009) Ecophysiology of cyanobacteria producing cyanotoxins. Oecol Bras 13(2):229-246. doi:10.4257 /oeco.2009.1302.02 in Portuguese

Monteiro NJC, Yunes JS, Bohrer-Morel MB (2006) Effects of the Microcystis aeruginosa strain RST9501 from Patos Lagoon, RS, on growth and reproduction of the Cladocera Ceriodaphnia dubia. J Braz Soc Ecotoxicol 1(1):93-96. doi:10.5132/jbse.2006.01.020

Moreira RA, Mansano AS, Silva LC, Rocha O (2014) A comparative study of the acute toxicity of the herbicide atrazine to cladocerans Daphnia magna, Ceriodaphnia silvestrii and Macrothrix flabelligera. Acta Limnol Bras 26(1):1-8. doi:10.1590/S2179-975 X2014000100002

Mowe MAD, Mitrovic SM, Lim RP, Furey A, Yeo DCJ (2015) Tropical cyanobacterial blooms: a review of prevalence, problem taxa, toxins and influencing environmental factors. J Limnol 74(2):205-224. doi:10.4081/jlimnol.2014.1005

Newcombe G, Chorus I, Falconer I, Lin TF (2012) Cyanobacteria: impacts of climate change on occurrence, toxicity and water quality management. Water Res 46(5):1347-1348. doi:10.1016/j. watres.2011.12.047

Nilin J, Castro CB, Pimentel MF, Franklin Júnior W et al (2007) Water toxicity assessment of the Ceará River Estuary (Brazil). J Braz Soc Ecotoxicol 2:1-7

Onda K, LoBuglio J, Bartram J (2012) Global access to safe water: accounting for water quality and the resulting impact on MDG progress. Int J Environ Res Public Health 9:880-894. doi:10.3390 /ijerph9030880

Oshima Y (1995) Postcolumn derivatization liquid chromatographic method for paralytic shellfish toxins. J AOAC Int 78(528-532). doi:10.1016/j.toxicon.2010.12.017

Phillips BM et al (2006) Solid-phase sediment toxicity identification evaluation in an agricultural stream. Environ Toxicol Chem 25(6): 1671-1676. doi:10.1897/05-497R1.1
Picone M, Bergamin M, Volpato E et al (2008) Sequential toxicity identification evaluation (TIE) for characterizing toxicity of Venice Lagoon sediments: comparison of two different approaches. Ecotox Environ Safe 72(2):538-545. doi:10.1016/j. ecoenv.2008.06.010

Pinto-Coelho RMP, Bezerra-Neto JF, Giani A et al (2003) The collapse of a Daphnia laevis (Birge 1878) population in Pampulha reservoir, Brazil. Acta Limnol Bras 15(3):53-70

Pouria S, Andrade A, Barbosa J et al (1998) Fatal microcystin intoxication in haemodialysis unit in Caruaru, Brazil. Lancet 352:21-26. doi:10.1016/S0140-6736(97)12285-1

Restani G, Fonseca AL (2014) Effects of Cylindrospermopsis raciborskii strains (Woloszynska, 1912) Senayya \& Subba Raju on the mobility of Daphnia laevis (Cladocera, Daphniidae). Braz J Biol 74(1):2331. doi:10.1590/1519-6984.09712

Reynolds CS, Dokulil M, Padisák J (2000) The trophic spectrum revisited: the influence of trophic state on the assembly of phytoplankton communities. Developments in hydrobiology. Hydrobiologia. Kluwer Academic Publishers, U.K 155 p

Rietzler AC, Viegas FP (2002) Water quality and sediment from Pampulha (MG) using toxicity tests with cladocerans. In: hydroenergetic resource: uses, impacts and integrated planning (volume 1) - Programa de Pós-graduação em Ciências da Engenharia Ambiental CRHEA-SHS-EESC-USP. RiMa, São Carlos 346p. (in Portuguese)

Rietzler AC, Fonseca AL, Lopes GP (2001) Heavy metals in tributaries of Pampulha reservoir, Minas Gerais. Braz J Biol 61(3):363-370. doi:10.1590/S1519-69842001000300004

Rietzler AC, Fonseca AL et al. (2010) Evaluation ofMaceió acute toxicity tests with cladocerans in the reservoir of Ibirité. In: ECOTOX - XI Congresso Brasileiro de Ecotoxicologia - Resumos, Bombinhas, SC. (in Portuguese)

Robin J, Wezel A, Bernette G, Arthaud F, Angelibeert S, Rosset V, Oertle B (2013) Biodiversity in eutrophicated shallow lakes: determination of tipping points and tools for monitoring. Hydrobiologia 723:6375. doi:10.1007/s10750-013-1678-3

Russo RC (1995) Ammonia, nitrite and nitrate. In: Rand GM (ed) Fundamentals of aquatic toxicology - effects, environmental fate, and risk assessment. Taylor \& Francis, Flórida, pp. 455-471p

Sales SCM (2009) Ecotoxicological assessment of water and sediment quality from Pampulha reservoir (MG) and its major tributaries. Master Thesis. Federal University of Minas Gerais. (in Portuguese)

Salomons W, Forstner V (1984) Metals in hidrocycle. Springer-Verlag, New York

Sant'Anna CL, Azevedo MTP, Werner VR, Dogo CR, Rios FR, De Carvalho LR (2008) Review of toxic species of cyanobacteria in Brazil. Algol Stud 126(1):251-265. doi:10.1127/1864-1318/2008 /0126-0251

Sant'Anna C, Carvalho LR, Fiore M, Silva-Stenico ME, Lorenzi AS, Rios FR, Konno K, Garcia C, Lagos N (2011) Highly toxic Microcystis aeruginosa strain, isolated from São Paulo-Brazil, produce hepatotoxins and paralytic shellfish poison neurotoxina. Neurotox Res 19(3):389-402. doi:10.1007/s12640-010-9177-Z

Schubauer-Beringan MK, Ankley GT (1991) The contribution of ammonia, metals and non-polar organic compounds to the toxicity of sediment interstitial water from an Illinois River tributary. Environ Toxicol Chem 10:925-939. doi:10.1002/etc.5620100709

Sibley PK, Ankley GT, Cotter AM, Leonard EN (1996) Predicting chronic toxicity of sediments spiked with zinc: an evaluation of the acidvolatile sulfide models using a life cycle test with the midge Chironomus tentans. Environ Toxicol Chem 15(12):2102-2112. doi:10.1002/etc. 5620151206

Silva LAP (2012) Effects of cyanobacterias on cladocerans Ceriodaphnia dubia and Daphnia gessneri. Master Thesis. Universidade Federal do Rio Grande do Norte (In Portuguese) 
Soares MC, Huszar VLM, Miranda MN, Mello MM, Roland F, Luring M (2013) Cyanobacterial dominance in Brazil: distribution and environmental preferences. Hydrobiologia 717(1):1-12. doi:10.1007 /s10750-013-1562-1

Society of Environmental Toxicology and Chemistry (1993) SETAC Guidance document on sediment toxicity tests and bioassays for freshwater and marine environments. In: Hill, IR, Matthiessen, P, Heimbach, F (eds) Workshop on sediment toxicity assessment. SETAC, Renesse, p 105

Sotero-Santos RB, Silva CRS, Verani NF, Nonakac KO, Rocha O (2006) Toxicity of a cyanobacteria bloom in Barra Bonita Reservoir (Middle Tietê River, São Paulo, Brazil. Ecotox Environ Safe 64: 163-170. doi:10.1016/j.ecoenv.2005.03.011

Spoof L, Vesterkvist P, Lindholm T, Meriluoto J (2003) Screening for cyanobacterial hepatotoxins, microcystins and nodularin in environmental water samples by reversed-phase liquid chromatographyelectrospray ionisation mass spectrometry. J Cromatography 1020 : 105-119. doi:10.1016/S0021-9673(03)00428-X

Takenaka RA, Dellamano-Oliveira MJ, Rocha O (2007) Toxicity of blooms of cyanobacteria of the Tiete River reservoirs, SP, on daphnids Ceriodaphnia dubia and Ceriodaphnia silvestrii (Cladocera, Crustacea). J Braz Soc Ecotoxicol 2(2):147-156. doi:10.5132/jbse.2007.02.007 in Portuguese

Thomas KV, Barnard N, Collins K, Eggleton G (2003) Toxicity characterization of sediment porewaters collected from UK. Estuaries using a Tisbe battagliai bioassay. Chemosphere 53(9):1105-1111. doi:10.1016/S0045-6535(03)00611-8

Tôrres IC (1999) Assessing of the influence of tributaries in the water quality from Pampulha reservoir. Master Thesis. Federal University of Minas Gerais. (in Portuguese)

Tundisi JG (1993) The environmental impact assessment of lakes and reservoirs. In: Salánki J, Itsvánovics V (eds) Limnological bases of lake management: proceedings of the ILEC/UNEP int. training course. Tihany, Hungary. $38-50 \mathrm{p}$

Tundisi JG (2001) Gerenciamento da qualidade da água: interações entre pesquisa, desenvolvimento tecnológico e políticas. Bras Pesq e Desenvolvimento 3(2):57-68

Tundisi JG (2003) Water Água no século XXI: enfrentando a escassez. RiMa, São Carlos 247p

Tundisi JG et al (1998) Aquatic biodiversity as a consequence of diversity of habitats and functioning mechanisms. Acad Bras Ci 70(4):767-773

UNEP/ILEC (2001a) Eutrophication management palmolare 2. Shallow Lakes. PDF available at: http://www.unep.or.jp/ietc/Publications/Short Series/LakeReservoirs-3/index.asp

UNEP/ILEC (2001b) Lakes and reservoirs: water quality: the impact of eutrophication. PDF available at: http://www.unep.or. jp/ietc/Publications/Short_Series/LakeReservoirs-3/index.asp

United States Environmental Protection Agency (1991) USEPA/600/0691/007. Sediment toxicity identification evaluation: phase I (characterization), phase II (identification) and phase III (confirmation) modifications of effluent procedures. Duluth

United States Environmental Protection Agency (1992) USEPA/823/R92/006. Sediment classification methods compendium. Environmental Protection Agency/Sediment Oversight Technical Commitee, Washington, D.C.

United States Environmental Protection Agency (2007) Sediment toxicity identification evaluation (TIE) — phases I, II, and III. Guidance Document (EPA/600/R-07/080)

Valério E, Faria N, Paulino S, Pereira P (2008) Seasonal variation of phytoplankton and cyanobacteria composition and associated microcystins in six Portuguese freshwater reservoirs. Ann Limnol - Int J Lim 44(3):189-196. doi:10.1051/limn:2008003

Van Sprang PA, Janssen CR (1997) Identification and confirmation of ammonia toxicity in contaminated sediments using a modified toxicity identification evaluation approach. Environ Toxicol Chem 6(12):2501-2507. doi:10.1002/etc.5620161210

Vasconcelos V, Morais J, Vale M (2011) Microcystins and cyanobacteria trends in a 14 year monitoring of a temperate eutrophic reservoir (Aguieira, Portugal). J Environ Monit 13:668-672. doi:10.1039/c0 em00671h

Vörösmarty CJ, Douglas EM, Green PA, Revenga C (2005) Geospatial indicators of 12 emerging water stress: an application to Africa. Ambio 34:230-236. doi:10.1579/0044-7447-34.3.230

Vörösmarty CJ, McIntyre PB, Gessner MO, Dudgeon D, Prusevich A, Green P, Glidden S, Bunn SE, Sullivan CA, Reidy Liermann C, Davies PM (2010) Global threats to human water security and river biodiversity. Nature 467:555-561. doi:10.1038/nature09440

Wang F, Chapman PM (1999) Biological implications of sulfide in sediment - a review focusing on sediment toxicity. Environ Toxicol Chem 18(11):2526-2532. doi:10.1002/etc.5620181120

Western D, Pearl MC (1989) Conservation: for the twenty-first century. Oxford University Press, Oxford $365 \mathrm{p}$

Wetzel RG (1991) Limnology: lake and river ecosystems, 1st. edn. Academic Press, New York

Whiteman FW (1996) Evaluation of interstitial water as a route of exposure for ammonia in sediment tests with benthic macroinvertebrates. Environ Toxicol Chem 15(5):794-801. doi:10.1002 /etc.5620150527

Yamada TM, Sueitt APE, Beraldo DAS et al (2012) Calcium nitrate addition to control the internal load of phosphorus from sediments of a tropical eutrophic reservoir: microcosm experiments. Water Res 46(19):6463-6475. doi:10.1016/j.watres.2012.09.018

Yu H, Shang H, Xu T, Cui Y, Yang L, Jin H, Wang L (2003) Application of toxicity identification evaluation procedures to an effluent from a nitrogenous fertilizer plant in China. Ecotox Environ Safe 57(3):426-430. doi:10.1016/S01476513(02)00011-8 